\title{
MILK Symposium review: The importance of milk and dairy foods in the diets of infants, adolescents, pregnant women, adults, and the elderly*
}

\author{
D. I. Givens† (ㅁ) \\ Institute for Food, Nutrition and Health, University of Reading, Reading RG6 6AR, UK
}

\begin{abstract}
The ongoing increase in life expectancy is not always accompanied by an increase in healthy life span. There is increasing evidence that dietary exposure in early life can substantially affect chronic disease risk in later life. Milk and dairy foods are important suppliers of a range of key nutrients, with some being particularly important at certain life stages. It is now recognized that milk protein can stimulate insulin-like growth factor-1 (IGF-1), essential for longitudinal bone growth and bone mass acquisition in young children, thus reducing the risk of stunting. Low milk consumption during adolescence, particularly by girls, may contribute to suboptimal intake of calcium, magnesium, iodine, and other important nutrients. Given the generally low vitamin D status of European populations, this may have already affected bone development, and any resulting reduced bone strength may become a big issue when the populations are much older. Suboptimal iodine status of many young women has already been reported together with several observational studies showing an association between suboptimal iodine status during pregnancy and reduced cognitive development in the offspring. There is now good evidence that consumption of milk and dairy foods does not lead to an increased risk of cardiovascular diseases and type 2 diabetes. Indeed, some negative associations are seen, notably between yogurt consumption and type 2 diabetes, which should be researched with urgency. Greater emphasis should be placed on reducing malnutrition in the elderly and on dietary approaches to reduce their loss of muscle mass, muscle functionality, and bone strength. Whey protein has been shown to be particularly effective for reducing muscle loss; this needs to be developed to provide simple dietary regimens for the elderly to follow.
\end{abstract}

\footnotetext{
Received January 31, 2020.

Accepted June 16, 2020

*Presented as part of the MILK Symposium: Improving Milk Production, Quality, and Safety in Developing Countries at the ADSA Annual Meeting, Cincinnati, Ohio, June 2019.

†Corresponding author: d.i.givens@reading.ac.uk
}

There is an ongoing, often too simplistic debate about the relative value of animal versus plant food sources for protein in particular. It is important that judgments on the replacement of dairy products with those from plants also include the evidence on relative functionality, which is not expressed in simple nutrient content (e.g., hypotensive and muscle synthesis stimulation effects). Only by considering such functionality will a true comparison be achieved.

Key words: milk, dairy, life stage, chronic disease

\section{INTRODUCTION}

In its recent review of world health statistics, the World Health Organization (WHO, 2019) reported that global life expectancy has continued to increase, on average by 5.5 yr from 2000 to 2016, although healthy life expectancy increased by only $4.8 \mathrm{yr}$ during the same period. However, there are great discrepancies, notably that life expectancy at birth is more than 18 yr shorter in low-income countries than in high-income countries. A sizable proportion of the difference is related to preventable health issues. Moreover, childhood obesity continues to increase across the world but most notably in Europe and North America.

In the United Kingdom (UK), life expectancy doubled over the last $200 \mathrm{yr}$ and is now higher than $80 \mathrm{yr}$ (Roser, 2017), with an even greater population growth rate among those aged $85 \mathrm{yr}$ and over. Aging brings with it some important nutrition-health challenges, such as increased risk of bone breakages and sarcopenia and challenges linked to lower absorption of vitamin $\mathrm{B}_{12}$ and efficiency of vitamin D synthesis. Gullberg et al. (1997) estimated the total worldwide number of hip fractures to be around 1.26 million in 1990, and they predicted that this would increase to 2.6 and 4.5 million by 2025 and 2050, respectively. In support of this, Hernlund et al. (2013) reported that the frequency of osteoporotic fracture has increased in many parts of the world and proposed that in the European Union (EU), the prevalence will double by 2035. It is therefore of considerable concern that in the UK, milk consumption during the teenage years is reduced, particularly 
in girls, such that considerable suboptimal intakes of calcium, iodine, and other key nutrients are apparent.

Sarcopenia is an age-related progressive loss of muscle mass and strength. The meta-analysis by Shafiee et al. (2017) reported that the overall prevalence of sarcopenia was $10 \%$ in men and women, but it was higher in non-Asian countries than in Asian countries. There are many effects of sarcopenia, including reduced muscle strength and mass leading to increased risk of falls and related bone breakages, which can have major negative effects on quality of life and independence. It is also now appreciated that both reduced muscle mass and reduced mobility can increase the risk of type 2 diabetes, which further reduces healthy and quality life span (Hunter et al., 2019).

In middle and later life, cardiovascular diseases (CVD) remain a major cause of death and morbidity in the EU and worldwide even though prevention and treatment programs have brought major benefits (Wilkins et al., 2017). Although CVD-related mortality has declined in most of Europe, there remain some 49 million people living with CVD in the EU, which represents a major health care cost (Wilkins et al., 2017). Of related concern is the substantial rise in the prevalence of type 2 diabetes related in good part to increased obesity. Recent data from Diabetes UK (2019) indicate that about $10 \%$ of people over $40 \mathrm{yr}$ of age now have type 2 diabetes, with some 4.7 million cases of all types of diabetes ( $90 \%$ type 2$)$. It is predicted that by 2030 the number of cases will have reached 5.5 million.

Diet is a key risk-modifying factor for chronic diseases, and this must be considered appropriately throughout the various life stages, not least because reducing risk in early life can have benefits in later life. The intention of this review is to focus on key life stage issues where milk and dairy components can play a substantial role in reducing chronic disease risk. This predominantly relates to high-income countries, although some reference is made to low-income countries where relevant.

\section{MILK IN CHILDHOOD}

\section{Milk and Growth}

The benefits of milk in a child's diet have been known for many years. For example, in 1926, a report produced by the UK Medical Research Council showed that giving an additional $568 \mathrm{~mL} / \mathrm{d}$ of milk to boys in a children's residential home led to a marked increase in growth (Corry Mann, 1926). Subsequently, UK nutrition policy encouraged milk drinking for children. In recent years there has been an increased focus on the importance of nutrition during childhood, as there is increasing evidence that diets during this period can influence health in later life. It is well recognized that undernutrition in childhood can lead to a marked reduction in linear growth (stunting), increased risk of slower short-term cognitive development, and, in adulthood, hyperglycemia, hypertension, elevated blood lipids, and obesity (de Onis and Branca, 2016). Despite recent worldwide improvements, Semali et al. (2015) noted that stunting in sub-Saharan African children remains at about $40 \%$, and some countries have an even higher prevalence. Recently, Leroy and Frongillo (2019) confirmed that childhood stunting remains a major health concern in many parts of the world. They also proposed that the conventional focus on linear growth reduction and stunting is not always the most cost-efficient way to improve the well-being of children.

Nevertheless, a range of studies over a substantial time period have shown milk to be a key food for reducing stunting in children. In the mid-1970s a randomized controlled trial (RCT) was started to evaluate the effect of milk provision at school on child growth (Baker et al., 1980). Some 600 children aged 7 and $8 \mathrm{yr}$ in families in South Wales, UK, with 4 or more children were chosen from schools in areas with a high socioeconomic deprivation. The selected children were on average $2.5 \mathrm{~cm}$ shorter and $1.5 \mathrm{~kg}$ lighter than the average for the area, and for height, they were representative of the lowest $20 \%$ of children throughout the whole region. The children in the treatment group were given $190 \mathrm{~mL}$ of milk every school day. After 2 school years, these children were significantly taller and heavier (both $P<0.01$ ) than those in the control group, although the increases were very small $(0.28 \mathrm{~cm}$ taller and $0.13 \mathrm{~kg}$ heavier). In addition, growth was significantly increased in children from families in the highest social classes compared with those in the lowest. More recently, Michaelsen (2013) emphasized that milk has a specific growth-promoting effect in children, an effect that is seen in both developing and developed countries, indicating an effect even when energy and nutrient intakes are apparently adequate. In a recent study in Bangladeshi children from households with milk-producing cows, Choudhury and Headey (2018) found that these children had increased height-for-age $\mathrm{Z}$ scores (+0.52 SD) in the crucial 6- to 23-mo growth phase compared with control children from households with non-milk-producing animals, an effect apparently not confounded by family socioeconomic status. However, it was also found that children aged 0 to $11 \mathrm{mo}$ from treatment households were $21.7 \%$ less likely to be breastfed than children from control households, suggesting that ready access to dairy milk substantially reduces the incentive for mothers to breastfeed. Reduced 
availability of breast milk is a considerable disadvantage for the very young child, with the increased acute risk of gastrointestinal infections and infant morbidity and mortality.

The effect of milk on linear growth is now thought to be primarily mediated through the stimulation of IGF-1 by milk proteins, in particular casein (Hoppe et al., 2009); IGF-1 is essential for longitudinal bone growth, skeletal maturation, and bone mass acquisition during childhood as well as maintenance of bone matrix in adult life (Locatelli and Bianchi, 2014). Regulation of bone length is associated with changes in chondrocytes of the proliferative and hypertrophic zones of the growth plate (Yakar et al., 2018). It is of note that Wan et al. (2017) showed that activation of peroxisome proliferator-activated receptor gamma $(\mathrm{PPAR} \gamma)$ is also involved in the regulation of hepatic IGF-1 secretion and gene expression in response to dietary protein, thus providing a possible explanation whereby dietary protein and related AA stimulate hepatic secretion of IGF-1.

\section{Milk, Obesity, and Future Health}

The general increase in childhood obesity in many parts of the world is a major concern. At least $60 \%$ of children who are overweight before puberty will remain overweight in early adulthood (Nittari et al., 2019), with the increased risk of CVD (Steinberger et al., 2016) and type 2 diabetes. It is therefore of considerable interest that dairy consumption is inversely and longitudinally associated with childhood obesity and overweight ( $\mathrm{Lu}$ et al., 2016; Dougkas et al., 2019). However, concerns exist about the early protein hypothesis; there is consistent evidence that the use of infant formulas with higher protein contents than human milk throughout the first year of life leads to greater abdominal fat mass in children aged 2 to 6 yr. This is likely to be related to higher circulating IGF-1 and insulin (Totzauer et al., 2018). Insulin in particular is known to promote adipose tissue deposition, and this is a key component of the early development of insulin resistance. Thus, in many Western populations there may be a need to moderate the use of high-protein formula milks in early life.

\section{Milk and Bone Health}

It is now recognized that suboptimal vitamin D status in children and adults is prevalent in many parts of the world. Holick (2010) proposed this to be a pandemic of "a forgotten hormone important for health." Cashman et al. (2016) confirmed that within Europe, the prevalence of vitamin $\mathrm{D}$ deficiency represented a major health risk that required a major public health initiative. More recently, Jazayeri et al. (2018) reported that the prevalence of vitamin D deficiency in Iranian children is very high.

A 2-yr intervention study with 757 Chinese girls initially aged $10 \mathrm{yr}$ compared those who consumed on school days $330 \mathrm{~mL}$ of calcium-fortified milk without or with a vitamin $\mathrm{D}_{3}$ supplement $(5$ or $8 \mu \mathrm{g}$ ). Over the intervention period, mean calcium intake was 649,661 , and $457 \mathrm{mg} / \mathrm{d}$ for the milk, milk plus vitamin $\mathrm{D}$, and control groups, respectively. Milk consumption with or without added vitamin D led to a significantly greater rate of height increase, BW, total bone mineral mass, and bone mineral density (BMD). The subjects who also received vitamin $\mathrm{D}$ relative to those receiving just milk showed significantly greater increases in (size-adjusted) total-body bone mineral content (2.4 vs. $1.2 \%$; $P=0.02)$ and BMD (5.5 vs. 2.2\%; $P<0.0005$; Du et al., 2004).

A study in the United States (US) with children aged 4 to 8 yr (Abrams et al., 2014) found that calcium intake, when not substantially deficient, was not highly related to bone mineral status and that a supplement of $25 \mu \mathrm{g} / \mathrm{d}$ of vitamin D in these children did not influence calcium absorption or bone mineral status. However, intake of magnesium and the amount absorbed were key predictors of BMD and bone mineral content. The authors proposed that this study is evidence that magnesium should be considered an important nutrient in relation to bone development. The extent to which these findings can be extended to other populations is at present uncertain, but milk and dairy products are important sources of magnesium for children (15-25\% of intake in the UK; Roberts et al., 2018) and are especially important during the phase of rapid bone growth in late childhood and early adolescence. It is also of note that low serum magnesium concentrations in men aged 42 to $61 \mathrm{yr}$ were associated with increased risk of bone fracture in the Japanese Kuopio Ischemic Heart Disease prospective study (Kunutsor et al., 2017).

It has been known for a long time that low vitamin D status in children could lead to the development of rickets and consequent increased risk of osteoporosis in later life. As noted by Holick (2010), at the start of the 20th century some $80 \%$ of children in North America and Europe suffered from rickets. Subsequently, in some countries the occurrence of rickets declined markedly as a result of vitamin $\mathrm{D}$ fortification of foods including milk and the policy of providing cod liver oil to children, and by the late 1930s rickets was essentially eradicated. It is therefore of considerable concern that cases of rickets are again increasing in the US (Thacher 
et al., 2013) and worldwide (Prentice, 2013). In the UK, Goldacre et al. (2014) reported that in England, the need for hospital treatment for rickets was at the highest level seen in the last $50 \mathrm{yr}$.

Many but not all new cases of rickets are the result of suboptimal vitamin D status, with some cases implicating suboptimal calcium intake. Milk is of course an excellent dietary source of calcium, and as noted above, milk proteins, especially casein, provide an anabolic stimulus for bone development (Hoppe et al., 2009). Although milk is not a naturally rich source of vitamin $\mathrm{D}$, it is an excellent medium for vitamin $\mathrm{D}$ fortification. Vitamin D fortification of milk has been a policy in the US and Canada for a long time. In Europe such a policy for liquid milk is limited to Finland, although Sweden and Norway do fortify some dairy products (Itkonen et al., 2018). Itkonen et al. (2018) also concluded that in countries that have a national policy of vitamin $\mathrm{D}$ fortification, dairy foods do make a substantial contribution to vitamin $\mathrm{D}$ intake, whereas in countries with no such policy or with only a few fortified dairy foods, the contribution is low. Given the evolving picture on rickets, considerably more attention should be focused on the importance of vitamin D fortification of milk. There is also concern about the increasingly popular plantbased milk alternative drinks, especially when used to replace milk for young children (Scholz-Ahrens et al., 2020). Many contain very little protein and have lower micronutrient concentrations than milk (Bath et al., 2017), and in some cases young children have become seriously ill as a result of consuming such milk alternatives (e.g., Fourreau et al., 2013; Le Louer et al., 2014).

\section{Hypersensitivity to Milk and Dairy Foods}

There are 2 main types of hypersensitivities (often called intolerances) relating to dairy food consumption: cow milk protein allergy and lactose intolerance. These are very different conditions that require medical diagnosis to avoid unnecessary or inappropriate removal of cow milk from a child's diet, which can have significant nutritional consequences.

Cow milk protein allergy is an adverse immune response to proteins in cow milk. $\beta$-Lactoglobulin and $\alpha_{S 1}$-casein (both absent in human milk) are often quoted as the 2 key allergenic proteins (Pastuszka et al., 2016), although many other milk proteins can be involved. Two subtypes of cow milk protein allergy are usually recognized: the IgE-mediated rapid onset and non-IgEmediated delayed onset variants (Vojdani et al., 2018). Anaphylaxis and related death are possible in severe cases of the rapid onset subtype (Turner et al., 2015). Cow milk protein allergy is the most common type of food allergy and usually affects very young children, al- though a high proportion are in remission by the age of 3 yr (Host and Halken, 2014). The increased prevalence of cow milk protein allergy has been suggested to be the result of increased use of cow milk as a substitute for human milk (Rangel et al., 2016), although the recent study of Munblit et al. (2020) reported that identification and management of symptoms of cow milk protein allergy are often not evidence based, suggesting that there may be considerable overdiagnosis.

Lactose intolerance is a nonallergic hypersensitivity that results from a reduced ability to digest lactose. Intestinal digestion and absorption of lactose require the enzyme lactase, and deficiency or insufficiency of lactase leads to malabsorption of lactose and subsequent digestive upset. The ability or otherwise to synthesize lactase is genetically determined. For a full and up-todate review of lactose intolerance and cow milk protein allergy, see Miles (2020).

\section{MILK IN ADOLESCENCE}

\section{Adolescence and Dietary Change}

Adolescence is the life period (10-19 yr; WHO, 1999) involving hormonal changes, rapid growth, and sexual maturation. There are also changing dietary habits and new motivations and challenges, some persisting into adulthood (Forbes and Dahl, 2010). The age of puberty onset has decreased substantially over the last $100 \mathrm{yr}$; currently, the UK average age for boys and girls is 12 and $11 \mathrm{yr}$, respectively (NHS, 2019).

In the UK, data from the National Diet and Nutrition Survey covering the period 2008/09-2011/12 (Bates et al., 2014) identified that adolescent girls in particular have considerably lower milk consumption than girls under $11 \mathrm{yr}$ of age, whereas older age groups have somewhat higher intakes (Figure 1). A similar picture has been seen in the more recent National Diet and Nutrition Survey covering a longer period (2014/15-2015/16; Roberts et al., 2018), and this will have contributed substantially to the lower intakes of some key nutrients by adolescent girls (Table 1 ).

The reasons for the lower intakes of milk by adolescent girls are not known with certainty. However, poor complexion or weight gain during adolescence are often attributed to milk consumption. The recent large meta-analysis of RCT on the association between milk and dairy consumption and body composition in children and adolescents $(\mathrm{n}=2,844 ; 6-18$ yr old) does not support the fattening belief, the primary finding being that consumption of milk and dairy foods is more likely to produce a lean body phenotype (Kang et al., 2019).

The very low intakes of magnesium by UK adolescent girls are worrying given the evidence concerning the 
Table 1. Percentage of 3 UK population groups with micronutrient intakes less than the lower reference nutrient intake (LRNI), and percentage achievement of the reference nutrient intake (RNI) for vitamin $\mathrm{D}^{1}$

\begin{tabular}{|c|c|c|c|c|c|c|c|}
\hline \multirow[b]{2}{*}{ Population } & \multicolumn{6}{|c|}{ LRNI } & \multirow{2}{*}{$\frac{\text { RNI }}{\text { Vitamin D }}$} \\
\hline & Iron & Calcium & Magnesium & Zinc & Selenium & Iodine & \\
\hline Boys $11-18$ yr & 12 & 11 & 27 & 18 & 26 & 14 & 20 \\
\hline Girls $11-18$ yr & 54 & 22 & 50 & 27 & 45 & 27 & 17 \\
\hline Women 19-64 yr & 27 & 11 & 11 & 8 & 47 & 15 & 21 \\
\hline
\end{tabular}

${ }^{1}$ Adapted from data in Roberts et al. (2018).

possible key association between magnesium status and bone mineral status (Abrams et al., 2014; Kunutsor et al., 2017) summarized above. Larson et al. (2009) noted that US National Survey longitudinal data suggest that only $53 \%$ of young men and $21 \%$ of young women (19-30 yr) have calcium intakes that meet recommendations. They also showed that in the Eating Among Teens study both male and female adolescents recorded significant reductions in calcium intake $(P<$ $0.001)$ and dairy food consumption $(P<0.001$; main reduction was in milk) from baseline (mean age of 15.9 yr) to early adulthood (mean age of $20.5 \mathrm{yr}$ ). The mean daily reduction in calcium intake was 153 and $194 \mathrm{mg}$ for female and male adolescents, respectively (both about $-15 \%$ ). It was also seen that greater availability of milk at meal times, a liking for milk, and peer support for healthy eating at baseline were associated with smaller reductions in calcium intake (Larson et al., 2009). Given the coexistence of suboptimal vitamin D status, the above data give rise to considerable concern.

\section{Milk and Bonetrophic Nutrients}

The US National Osteoporosis Foundation's position paper concerning peak bone mass development (Weaver et al., 2016) emphasized that bone mineral accretion rate becomes rapid around the time of puberty and reaches its peak a little after achieving maximum height gain. Weaver et al. (2016) indicated that for children of European ancestry, maximum bone mineral accretion rate occurs at age $12.5 \pm 0.90 \mathrm{yr}$ for girls and $14.1 \pm$ 0.95 yr for boys. They emphasized that suboptimal bone mineral accretion in teenage years increases the risk of osteoporotic fractures in later life, particularly for postmenopausal women. This is supported by the study of Black et al. (2002), which found that male and female New Zealand children with a long history of avoiding milk had poor bone health with small bones, low areal BMD and volumetric bone mineral apparent density, and a high prevalence of bone fractures. Also, Kalkwarf et al. (2003) used data from 3,251 white women in the

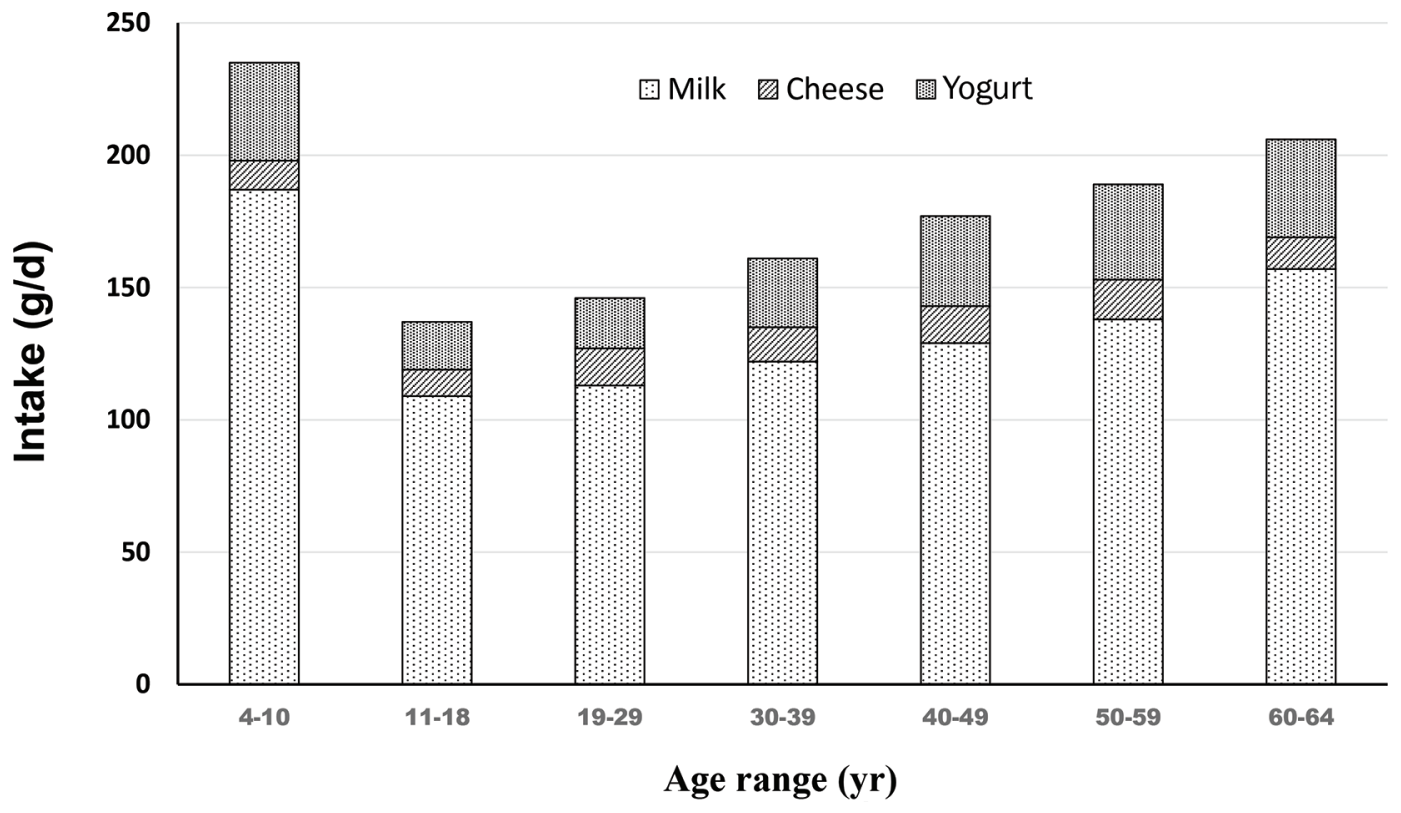

Figure 1. Mean dairy food intake in UK women according to age group. Adapted from the data of Bates et al. (2014). 
Table 2. Effects of vegetarian and vegan diets relative to omnivore diets on bone mineral density (BMD) at the lumbar spine, at the femoral neck, and of whole body ${ }^{1}$

\begin{tabular}{lccc}
\hline & $\begin{array}{c}\text { Mean difference } \\
\text { in } \mathrm{BMD}^{2}\left(\mathrm{~g} / \mathrm{cm}^{2}\right)\end{array}$ & $95 \% \mathrm{CI}$ & $P$-value $^{3}$ \\
\hline BMD comparison & & & \\
\hline Vegetarians + vegans vs. omnivores & -0.032 & $-0.048,-0.015$ & $<0.05$ \\
$\quad$ Vegetarian vs. omnivores & -0.023 & $-0.035,-0.010$ & $<0.05$ \\
$\quad$ Vegans vs. omnivores & -0.070 & $-0.116,-0.025$ & $<0.05$ \\
At the femoral neck & -0.037 & $-0.054,-0.020$ & $<0.05$ \\
$\quad$ Vegetarians + vegans vs. omnivores & -0.025 & $-0.038,-0.012$ & $<0.05$ \\
$\quad$ Vegetarian vs. omnivores & -0.055 & $-0.090,-0.021$ & $<0.05$ \\
$\quad$ Vegans vs. omnivores & -0.048 & $-0.080,-0.016$ & $<0.05$ \\
Whole body & -0.035 & $-0.093,0.022$ & $\mathrm{NS}$ \\
$\quad$ Vegetarians + vegans vs. omnivores & -0.059 & $-0.106,-0.012$ & $<0.05$ \\
$\quad$ Vegetarian vs. omnivores & & & \\
$\quad$ Vegans vs. omnivores & & & \\
\hline${ }^{1}$ Adapted from data in Iguacel et al. $(2019)$. & & & \\
${ }^{2}$ Compared with omnivores. & & & \\
${ }^{3}$ For test if difference was $>0$. & & &
\end{tabular}

US National Health and Nutrition Examination Survey and reported that milk consumption in childhood and adolescence was positively associated with bone mass in later life and negatively associated with osteoporotic fracture after $50 \mathrm{yr}$ of age. It is of interest that the association between milk intake in childhood and fracture rate was higher than that for milk consumption during the period of adolescence. This issue was also raised by Feskanich et al. (2014), who, in an analysis of postmenopausal women in the Nurses' Health Study, found no association between hip fractures and milk consumption in teenage years. They queried whether data for milk consumption during preteenage years would have been more helpful because girls reach maximum height about 2 yr sooner than boys and are younger at the start of puberty when bone mineralization doubles (Feskanich et al., 2014). There must also be a question about the quality of recall of diet data from adulthood back to adolescence and childhood.

More recently, the study by Ma et al. (2014) reported that in Chinese adolescents (12-14 yr of age), girls in the high-calcium intake group (mean 1,243 mg/d) had greater increases in BMD of the femoral neck relative to those in the low-calcium intake group (mean 706 $\mathrm{mg} / \mathrm{d}$ ) over the 12-mo intervention period. A similar effect was observed in boys. They proposed that to increase bone mineral mass, calcium supplementation is more effective in early puberty than in late puberty and that children should be encouraged to increase their weight-bearing exercise, which enhances the effect of dietary calcium.

The strength of evidence for effects of milk and bonetrophic nutrients on bone development in adolescents is fairly strong, but more uncertainty remains about the effect on bone health in middle and later life following long-term exposure to diets low in or devoid of milk and dairy. Also, a recent systematic review and meta-analysis of the associations between vegan and vegetarian diets and bone health gives further evidence on the chronic effect of diets containing low or zero milk and dairy products (Iguacel et al., 2019). Twenty studies of adequate quality were included in the metaanalysis of Iguacel et al. (2019), which included 37,134 participants, of which 33,131 had data on fracture rate and 4,003 had data on BMD. Overall, compared with omnivores, vegetarians and vegans had significantly lower BMD at the femoral neck, lumbar spine, and whole body, with vegans generally exhibiting lower BMD than vegetarians (Table 2). Vegans also had a higher relative risk for fracture rate (relative risk: 1.44; 95\% CI: 1.047-1.977), particularly in subjects aged over $50 \mathrm{yr}$. These findings highlight the absolute need for careful, detailed, and long-term planning of vegetarian and vegan diets in order to reduce the risk of negative effects on bone health.

A review on milk and bone health (Batty and Bionaz, 2019) provided some new thinking on the mechanisms concerning the role of milk in bone development, including the possible role of microRNA (miRNA) contained in milk. Although there appears to be considerable but building evidence that endogenous miRNA is involved in regulation of osteoblastic differentiation and other pathways relevant to bone development in adolescents, uncertainly remains about the effect of miRNA provided by the diet in the form of exosomes. Zempleni (2017) has shown that exosomes are absorbed and can accumulate in peripheral tissues, but the functionality of their miRNA is unclear. At present the possible 
involvement of milk-derived exosomes and miRNA in bone development and maintenance remains speculative and is clearly a target for further research.

\section{MILK AND PREGNANCY}

\section{lodine Status During Pregnancy}

In the UK and many other countries, milk and milk products are the biggest dietary source of iodine by a considerable margin. The recent UK National Diet and Nutrition Survey (year 8, 2014/15-2015/16; Roberts et al., 2018) reported that milk and milk products contribute 40 and $34 \%$ of dietary iodine intake for the 11-18 yr and 19-64 yr age groups, respectively, with liquid milk being the primary dairy source. Fish is the next largest contributor to dietary intake at $10 \%$ for both age groups. Interestingly, milk and dairy products were also shown to be the most important determinant of iodine status in US adults ( $\geq 20 \mathrm{yr})$ men and women despite the availability of iodized salt (Lee et al., 2016).

Until fairly recently it was believed that the UK population was of adequate iodine status. However, a study that measured iodine concentrations of urine from UK schoolgirls showed $51 \%$ of them to be mildly iodine deficient (Vanderpump et al., 2011). As noted earlier, $27 \%$ of adolescent girls (11-18 yr) have iodine intakes below the lower reference nutrient intake $(70 \mu \mathrm{g} / \mathrm{d})$, and the mean value for women aged 19 to $64 \mathrm{yr}$ is $15 \%$ (Roberts et al., 2018; Table 1). Given the milk intake values in Figure 1, women of childbearing age are likely to exceed this value substantially. Of particular concern are the results from a study in a large UK cohort of pregnant women that showed consistent mild to moderate iodine deficiency (Bath et al., 2014), with similar findings in pregnant Norwegian women (Brantsæter et al., 2013). Bath and Rayman (2015) reviewed the then-current evidence on the iodine status of pregnant women in the UK and the risks to child development after birth (as discussed below) associated with belowoptimum status. They concluded that a substantial proportion of UK pregnant and nonpregnant women were iodine deficient. The WHO database on iodine deficiency (WHO, 2020) highlights that large parts of the world are affected, with substantial parts of Africa and Asia having mild or moderate deficiency. Example studies include one from Tanzania that reported an unacceptably high prevalence of iodine deficiency among pregnant women (Mtumwa et al., 2017), and a recent assessment on the iodine status of teenage girls on the island of Ireland (Mullan et al., 2020) showed that this population was at "the low end of sufficiency," which clearly has implications for their future progression into pregnancy and for child development after birth (as discussed below).

Bath and Rayman (2015) also discussed the potentially contributing fact that the UK recommendation for iodine intake of $140 \mu \mathrm{g} / \mathrm{d}$ for adults (Department of Health, 1991) is not only lower than what WHO Secretariat et al. (2007) recommends for nonpregnant and nonlactating adults and adolescents ( $>12 \mathrm{yr}$ of age; $150 \mu \mathrm{g} / \mathrm{d}$ ) but also does not increase during pregnancy (or lactation), whereas WHO Secretariat et al. (2007) recommends an increase to $250 \mu \mathrm{g} / \mathrm{d}$. There are clear needs for a greater iodine intake during pregnancy, including the demands associated with substantially increased maternal thyroid hormone production in early pregnancy and later for the fetus when it is able to synthesize thyroid hormones (Bath and Rayman, 2015).

It is concerning to note that several studies from several countries including Spain (Costeira et al., 2011), the Netherlands (van Mil et al., 2012), Australia (Hynes et al., 2013), and the UK (Bath et al., 2013) have found a significant association between low maternal iodine status in early pregnancy and poorer cognitive performance and neurological development in the children. A systematic review and meta-analysis found that low maternal iodine status was associated with 6.9 to 10.2 lower IQ points in children $<5$ yr of age (Bougma et al., 2013). They concluded that independent of study type, low iodine status had a major effect on mental development. It is also worth noting that Businge et al. (2019) reported that although subclinical hypothyroidism during pregnancy is one of the key risk factors for pre-eclampsia, the connection between suboptimal iodine status and pre-eclampsia remains uncertain. Given the risks associated with pre-eclampsia, Businge et al. (2019) proposed that a systematic review and metaanalysis on the subject should be undertaken.

Given the potentially serious implications of suboptimal iodine status on child development, there is a clear need for more precise RCT to give more definitive evidence of the need for supplementary iodine during pregnancy to avoid impaired neurological development of the offspring. Such studies would no doubt raise important ethical considerations, but it is interesting to note that in the study of Bath et al. (2014), only women consuming more than $280 \mathrm{~mL}$ of milk/d achieved adequate iodine status, and a recent RCT in women consuming low to moderate amounts of milk $(<250 \mathrm{~mL} / \mathrm{d})$ showed that increasing consumption to $459 \mathrm{~mL} / \mathrm{d}(3 \mathrm{~L} / \mathrm{wk})$ of semi-skimmed (reduced-fat) milk significantly increased their iodine status (O'Kane et al., 2018). The volume of milk needed to achieve an adequate iodine intake clearly depends on its iodine concentration, which can vary substantially. 


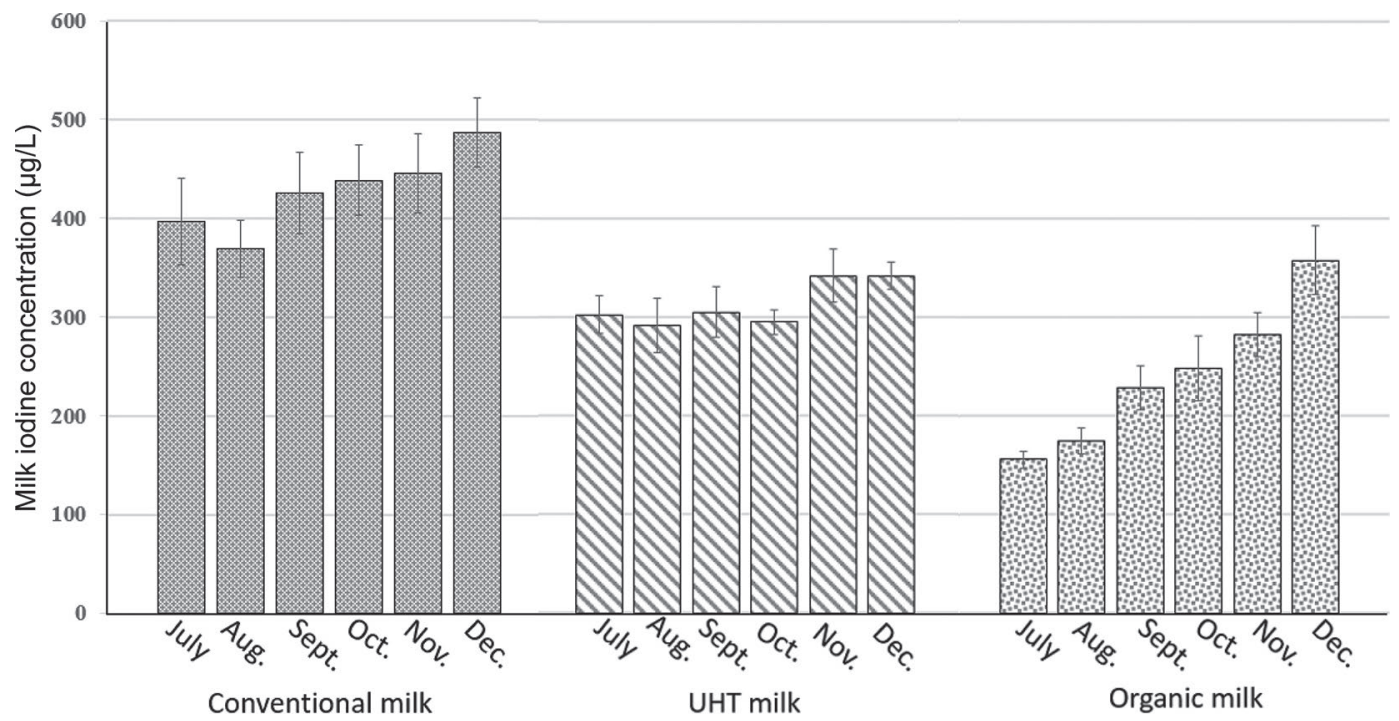

Figure 2. Effect of season and milk type on the mean iodine concentration of UK retail milk in 2015. Error bars are \pm SE. Adapted from the data of Stevenson et al. (2018).

\section{Factors Affecting the lodine Concentration in Milk}

Survey studies on UK milk iodine concentrations (Food Standards Agency, 2008) do not suggest that milk iodine concentration has declined, but they do show that milk produced in summer has on average a $50 \%$ lower iodine concentration than milk produced in winter. Moreover, 4 UK studies (Food Standards Agency, 2008; Bath et al., 2012; Payling et al., 2015; Stevenson et al., 2018) and the meta-analysis of Średnicka-Tober et al. (2016) all reported that milk from organic dairy systems had significantly lower iodine concentrations than that from conventional systems. The interacting involvement of season and production system on milk iodine concentration can be seen in Figure 2 in Stevenson et al. (2018). The review by Flachowsky et al. (2014) confirms that iodine intake by the dairy cow is the primary influence on milk iodine concentration. Most iodine is provided to the cow by concentrate feeds, which explains the lower values reported in milk in the summer and from organic systems; the animals in both situations are likely to be provided with less concentrate feeds. The effect of iodine supplements (30 or 70 $\mathrm{mg} / \mathrm{d})$ to dairy cows were compared with a control $(0$ $\mathrm{mg} / \mathrm{d}$ ). Iodine concentration increased approximately 2 -fold in the milk of the supplemented animals compared with the nonsupplemented animals. No difference was seen between the 30 and $70 \mathrm{mg} / \mathrm{d}$ doses (O'Brien et al., 2013). It is important to note that the iodine concentrations in milk from the iodine-supplemented diets were much higher (up to $1,034 \mu \mathrm{g} / \mathrm{kg}$ ) than is desirable for processing into infant formula products. As the authors pointed out, the supplemented diets did not contain more iodine than the maximum prescribed in the present EU legislation (5 $\mathrm{mg}$ of iodine/ $\mathrm{kg}$ of diet at $12 \%$ moisture; European Commission, 2005). O'Brien et al. (2013) also showed that the use of iodine-containing teat disinfection products both preand postmilking increased milk iodine concentration $(P$ $<0.001)$ at all of the dietary iodine supplementation amounts. This and several additional factors that influence milk iodine concentration are extensively reviewed by Flachowsky et al. (2014). Overall, knowledge of the relationship between iodine in the dairy cow diet and milk iodine concentration, together with other factors, provides a means to produce milk with the required iodine concentration for consumption by adults while avoiding concentrations that are too high for children.

\section{MILK IN ADULTHOOD}

\section{Milk Consumption and Body Composition}

The prevalence of overweight and obesity (body mass index of $30 \mathrm{~kg} / \mathrm{m}^{2}$ or more) continues to rise worldwide. The Organisation for Economic Co-operation and Development (OECD) reported that since the 1990s overweight and obesity rates have increased substantially in England, Mexico, and the US; the increase has been somewhat slower in the other 7 OECD countries for which data are available (OECD, 2017). It was also noted that in 2015, 19.5\% of adults in OECD countries 
were obese, but this was highly variable (e.g., $<6 \%$ in Korea and Japan but $>30 \%$ in Hungary, New Zealand, Mexico, and the US).

Obesity is a major risk factor for chronic diseases, particularly diabetes, CVD, stroke, and some cancers. The association between obesity or overweight and type 2 diabetes is particularly critical, accounting for some 70 to $90 \%$ of the risk for type 2 diabetes (Hu et al., 2001; Gatineau et al., 2014), although there remains some uncertainty why some obese subjects do not develop type 2 diabetes (Abdullah et al., 2010).

It is not the intention of this paper to review in detail all the evidence on the association between milk and dairy and obesity. However, a large amount of evidence from observational, cross-sectional, and prospective studies is consistent with a negative association between dairy consumption and both BW and central obesity (Dougkas et al., 2011). The review by Kratz et al. (2013), using observational and RCT evidence, found that in 11 out of 16 studies, high-fat dairy consumption was inversely associated with measures of adiposity, whereas the association between high-fat dairy and metabolic health was either inverse or nonexistent. The recent report on middle-aged men (at baseline) in the Caerphilly Prospective Cohort showed no association between milk consumption and body mass index, but higher cheese consumption was associated with lower body mass index at the 5 -yr follow-up $(P=0.013$; Guo et al., 2018).

Many RCT have evaluated the association between dairy consumption and $\mathrm{BW}$ and fat mass, but the majority have been small and of limited duration. Also, although some have included energy restriction, others have focused on weight maintenance, and the overall findings are difficult to interpret. Nevertheless, a meta-analysis of $29 \mathrm{RCT}$ of varied designs showed that although the inclusion of dairy foods in weight maintenance diets is not associated with weight loss or weight gain, there were weight loss benefits from the combination of these foods and energy-restricted diets (Chen et al., 2012).

\section{Milk Consumption, Stroke, CVD, and Metabolic Diseases}

It is interesting to note that although in most highincome countries the prevalence of death from CVD has decreased considerably over recent decades, it is concerning that recent data from the US indicate a leveling-off of the decline, thought probably to be a result of increasing obesity and related type 2 diabetes (Zia et al., 2018). These data highlight the risk of complacency and the continued need for the management of lifestyle, including diet. In this regard and as noted above, the effect of dairy foods in the diet is poorly understood by many in the general population.

\section{Evidence from Prospective Studies}

Many prospective studies have investigated the association between milk and dairy product consumption and cardiometabolic diseases (CMD; includes CVD, stroke, and type 2 diabetes). Data from prospective cohort studies are usually regarded as providing poorer evidence than RCT because they only estimate risk and cannot prove cause and effect, but they do have the advantage of looking at chronic effects and use hard disease data outcomes. Another limitation of this type of study is the presence of variables (confounders) that are beyond the control of the researchers (e.g., some subjects may be smokers and some will not) but that can influence the variables being studied (e.g., the effect of cheese consumption on the risk of CVD), leading to results that do not represent the actual association. This is normally dealt with by including the confounder in the statistical model used so that its effect is removed as far as possible; however, there often remains some residual confounding that is not accounted for. Long-term RCT using hard disease endpoints would be impractical, very costly, and likely have high subject dropout rates. Therefore, most RCT are relatively short term and use markers of disease risk such as lowdensity lipoprotein cholesterol (LDL-C) as primary outcome measures. Meta-analysis of prospective data is a valuable tool for investigating the overall associations between dairy food consumption and CMD risk, although there is a concern that in many studies these foods are poorly defined, especially their fat content, which limits assessment of any differential effects.

Although several other meta-analyses have been published recently, a series of dose-response meta-analyses was published in 2016/17 examining the association between dairy food consumption and type 2 diabetes

Table 3. Dose-response meta-analyses examining the relative risk $(\mathrm{RR})$ of cardiometabolic diseases in relation to consumption of dairy foods ${ }^{1}$

\begin{tabular}{lllc}
\hline Disease outcome & Dairy food & $\mathrm{RR}^{2}(95 \% \mathrm{CI})$ & $P$-value \\
\hline Diabetes mellitus & Total dairy & $0.97(0.95-1.00)$ & $\mathrm{NS}$ \\
& Low-fat dairy & $0.96(0.92-1.00)$ & $\mathrm{NS}$ \\
& Yogurt & $0.94(0.91-0.97)$ & $<0.05$ \\
Coronary heart disease & Total dairy & $1.00(0.98-1.03)$ & $\mathrm{NS}$ \\
& Milk & $1.01(0.97-1.04)$ & $\mathrm{NS}$ \\
Stroke & Total dairy & $0.98(0.96-1.01)$ & $\mathrm{NS}$ \\
& Low-fat dairy & $0.97(0.95-0.99)$ & $<0.05$ \\
& Full-fat dairy & $0.96(0.93-0.99)$ & $<0.05$ \\
& Milk & $0.92(0.88-0.97)$ & $<0.05$ \\
\hline
\end{tabular}

${ }^{1}$ Adapted from data in Soedamah-Muthu and de Goede (2018).

${ }^{2}$ Per increment of $200 \mathrm{~g} / \mathrm{d}$ except for yogurt $(100 \mathrm{~g} / \mathrm{d})$. 
(Gijsbers et al., 2016), stroke (de Goede et al., 2016), CVD, and all-cause mortality (Guo et al., 2017). The availability of new data has allowed key components of these meta-analyses to be updated (Soedamah-Muthu and de Goede, 2018), and the outline results are presented in Table 3.

Overall, these prospective studies show no increase in risk of coronary heart disease (CHD) and stroke per 200-g increase in total dairy and milk. Interestingly, consumption of milk and yogurt was associated with a substantially reduced risk of stroke and type 2 diabetes, respectively. The reduced risk of type 2 diabetes associated with yogurt consumption was also highlighted in the recent review of evidence by Guo et al. (2019). Few studies have looked into the association between butter consumption and CMD, although the dose-response meta-analysis of Pimpin et al. (2016) showed no significant association between butter consumption and all-cause mortality, CVD, CHD specifically, or stroke, although there was a significant $(P=0.031)$ negative association with type 2 diabetes. This meta-analysis involved only a few cohorts for CVD $(\mathrm{n}=4)$, CHD $(\mathrm{n}=$ $3)$, and stroke $(\mathrm{n}=3)$, although 11 cohorts were judged to be suitable for inclusion for type 2 diabetes. More recently, Griffin and Lovegrove (2018) raised the possibility that increased high density lipoprotein-mediated cholesterol efflux capacity compensates for the adverse effect of SFA in butter in raising blood LDL-C.

The Prospective Urban Rural Epidemiology (PURE) study (Dehghan et al., 2018), a multinational cohort study of 136,384 subjects aged 35 to 70 yr from 21 countries $(6,11$, and 4 low-, middle-, and high-income countries, respectively) across 5 continents, recently published its results. The study examined the association of consumption of dairy foods (total and milk, yogurt, and cheese) with mortality and CVD. Higher intake of total dairy foods ( $>2$ servings/d vs. none) was associated with a lower risk of non-CVD mortality (hazard ratio, HR: 0.86 ; 95\% CI: $0.72-1.02 ; P_{\text {trend }}=$ 0.046), CVD mortality (HR: 0.77; 95\% CI: 0.58-1.01; $\left.P_{\text {trend }}=0.029\right)$, major CVD events (HR: $0.78 ; 95 \%$ CI: $0.67-0.90 ; P_{\text {trend }}=0.0001$ ), and stroke (HR: $0.66 ; 95 \%$ CI: $\left.0.53-0.82 ; P_{\text {trend }}=0.0003\right)$. Greater consumption of milk and yogurt, but not cheese, was associated with a lower risk of the combination of mortality or major CVD events. Although the results from PURE are largely in agreement with earlier studies and meta-analyses, it is believed to be the first study of its kind to involve such large and diverse cohorts of subjects with substantial variation in habitual dairy and other dietary component intake between regions and countries.

Overall, the findings from meta-analyses of prospective cohort studies provide no evidence of an increased risk of CMD associated with increased consumption of dairy foods despite most of these foods making a major contribution to SFA intake. These findings may seem counterintuitive in view of the well-established link between LDL-C and CVD. However, emerging evidence goes some way to explain these relationships, including differential effects of different SFA and the food matrix influences (Thorning et al., 2017; Astrup et al., 2019).

Several prospective studies have also examined the association between milk and dairy intake and blood pressure. Findings from the Caerphilly Prospective Study indicate that after a 22.8-yr follow-up, men who consumed $>586 \mathrm{~mL} / \mathrm{d}$ of milk had a mean lower systolic blood pressure of $10.4 \mathrm{~mm} \cdot \mathrm{Hg}$ compared with men who did not consume milk ( $P_{\text {trend }}=0.033$; Livingstone et al., 2013).

\section{Evidence from RCT}

The American Heart Association recently reported that in 2015 the proportion of US adults $\geq 18 \mathrm{yr}$ of age with diagnosed hypertension was $29.7 \%$ (age adjusted), although there was considerable variability, with equivalent values ranging from $24.2 \%$ for Minnesota to $39.9 \%$ for Mississippi (Benjamin et al., 2018). Data from 2016 in England indicate that 28\% of adults had diagnosed hypertension (National Statistics, 2017a). In addition, substantial numbers of individuals have undiagnosed hypertension. Hypertension is one of the major risk factors for CVD and for stroke in particular.

There is now good evidence that the proteins in milk and milk-derived products, particularly whey proteins, have beneficial hypotensive effects. This has been shown in vitro (Giromini et al., 2017) and in vivo. An 8-wk RCT (Fekete et al., 2016) found that whey protein isolate $(2 \times 28 \mathrm{~g} / \mathrm{d})$ had a larger hypotensive effect than casein, with effects seen on both central and peripheral blood pressures. Whey protein was also shown to have a greater effect than casein in an acute setting (Fekete et al., 2018). Several mechanisms by which milk and its components could lower blood pressure have been proposed, including the effects of dairy nutrients, in particular calcium, potassium, and magnesium (Kris-Etherton et al., 2009), and the effect of milk protein-derived peptides (Fekete et al., 2013). Several peptides released during digestion of casein and whey proteins possess hypotensive activity through inhibiting the action of the angiotensin-1-converting enzyme that would normally increase the production of angiotensin-2, which has a vasoconstricting effect, leading to increased blood pressure (FitzGerald and Meisel, 2000; Giromini et al., 2019). Other effects of milk protein-derived peptides may be important, such 
as binding with opioid receptors, thus increasing nitric oxide production, which mediates arterial tone and thus reduces blood pressure (Kris-Etherton et al., 2009).

Recent work on hemodynamics has shown that arterial stiffness, especially of the central large vessels, is a valuable predictor of future CVD events (Cockcroft and Wilkinson, 2000). Milk and dairy consumption have been shown to be associated with reduced arterial stiffness. Livingstone et al. (2013), working with the Caerphilly Prospective Study, showed for the first time in a longitudinal study that augmentation index (an indirect measure of arterial stiffness) was $1.9 \%$ lower in subjects with the highest dairy product consumption (not including butter) compared with the lowest consumption $\left(P_{\text {trend }}=0.021\right)$ after a mean follow-up period of $22.8 \mathrm{yr}$. A similar effect was seen in a cross-sectional study that showed a negative association between milk and dairy consumption and pulse wave velocity (another indirect measure of arterial stiffness; Crichton et al., 2012). More recently, the specific effect of milk proteins together with exercise has been shown to reduce arterial stiffness in prehypertensive and hypertensive young women (Figueroa et al., 2014). Whey protein and casein both significantly $(P<0.05)$ reduced arterial stiffness as indicated by reduced augmentation index by about 9.2 and $8.1 \%$, respectively, and reduced pulse wave velocity by 57 and $53 \mathrm{~cm} / \mathrm{s}$, respectively, compared with no changes in the control group.

\section{Food Matrix Effects of Dairy Products on Blood Lipids}

New evidence on the food matrix goes a considerable way toward explaining the lack of effect of dairy SFA on CVD risk. This topic was extensively discussed recently by Astrup et al. (2019) and will not be fully repeated here, but aspects of food matrix effects are worthy of mention.

Traditionally, nutritional evaluation of foods and diets and their links with the health or disease of the consumer has focused on food components, notably protein, fat, carbohydrates, and micronutrients. For some dairy foods, there is now good evidence that this approach is not appropriate and indeed may mislead because the modifying effects of the so-called food matrix need to be considered. This subject was extensively reviewed by an expert working party jointly established by the Universities of Copenhagen and Reading, and the outcome was published (Thorning et al., 2017).

A good illustration of the differential matrix effects on blood lipids of SFA from hard cheese and butter is reported in the RCT of Hjerpsted et al. (2011). This involved two 6 -wk crossover periods with 49 men and women replacing part of their habitual dietary fat with $13 \%$ of energy from cheese or butter (both providing 80 and $36 \mathrm{~g} / \mathrm{d}$ of total fat and SFA, respectively). Crucially, the cheese and butter diets provided 1,192 and $417 \mathrm{~g}$ of calcium/d, respectively. Compared with baseline, cheese did not increase blood total cholesterol or LDL-C, whereas the butter diet increased both of these $(P<0.001$ and 0.05 , respectively $)$. The cheese diet led to 5.7 and $6.9 \%$ lower total cholesterol or LDL-C concentrations, respectively, compared with the butter diet $(P<0.0001)$. The recently published and rather unique study of Feeney et al. (2018) attempted to explore the matrix effect in a stepwise-response fashion. The study was a 6 -wk randomized parallel design where subjects consumed $40 \mathrm{~g}$ of dairy fat/d in macronutrient-matched food matrices as (1) $120 \mathrm{~g}$ of full-fat cheddar cheese, (2) $120 \mathrm{~g}$ of reduced-fat cheddar cheese plus $31 \mathrm{~g}$ of butter, or (3) $49 \mathrm{~g}$ of butter plus $30 \mathrm{~g}$ of calcium caseinate and $500 \mathrm{mg}$ of calcium as $\mathrm{CaCO}_{3}$. The blood lipid responses are summarized in Table 4 . The results did indeed show a stepwise-matrix effect in which significantly lower postintervention total cholesterol and LDL-C concentrations were seen when all of the dairy fat was provided by the cheese.

Several mechanisms have been proposed as being responsible for the benefits of the so-called matrix effect, and these are reviewed in detail by Thorning et al.

Table 4. Changes in blood lipids from baseline to end of 6 -wk intervention when $40 \mathrm{~g} / \mathrm{d}$ of dairy fat was provided in 3 types of dairy products ${ }^{1}$

\begin{tabular}{lcccc}
\hline & \multicolumn{3}{c}{ Treatment $^{2}$} \\
\cline { 2 - 4 } Blood lipid (mmol/L) & T1 & T2 & T3 & P-value \\
\hline Total cholesterol & -0.52 & -0.37 & -0.15 & 0.033 \\
High-density lipoprotein cholesterol & 0 & -0.07 & +0.05 & 0.284 \\
Low-density lipoprotein cholesterol & -0.45 & -0.27 & -0.14 & 0.016 \\
Triacylglycerols & -0.15 & -0.05 & -0.12 & 0.386 \\
\hline
\end{tabular}

${ }^{1}$ Adapted from data in Feeney et al. (2018).

${ }^{2} \mathrm{~T} 1=120 \mathrm{~g}$ of Cheddar cheese; T2 $=120 \mathrm{~g}$ of low-fat Cheddar cheese $+21 \mathrm{~g}$ of butter; $\mathrm{T} 3=49 \mathrm{~g}$ of butter $+30 \mathrm{~g}$ of calcium caseinate $+500 \mathrm{mg}$ of calcium $\left(\right.$ as $\left.\mathrm{CaCO}_{3}\right)$.

${ }^{3}$ For differences between treatments; for controlling factors included in model, see original paper. 
(2017). In brief, most studies involving hard cheese result in increased fecal fat and calcium excretion, which at least in part seems to be the result of a saponification reaction in the gut between calcium and fatty acids leading to largely indigestible soaps. There is also evidence that fecal bile acid excretion is increased due to adsorption on amorphous calcium phosphate formed from dietary calcium and phosphorus. This reduces the enterohepatic recycling of bile acids, thus increasing bile acid and fat excretion. Because the liver synthesizes bile acids from cholesterol, reduced bile acid recycling may also lead to reduced circulating cholesterol. There is also evidence of a role for the milk fat globule membrane apparently protecting fat from digestion. A good example of this is in the study of Rosqvist et al. (2015).

These studies clearly confirm that the effect of dairy foods on CVD risk factors, primarily blood lipids, are influenced by the food matrix, even when compared with foods providing the same amount of dairy fat and SFA. However, most of the evidence available relates to hard cheese versus butter. As proposed by Thorning et al. (2017), more research is required to more fully understand food matrix effects on health and how these relate to specific dairy foods and methods of processing and cooking.

\section{MILK AND DAIRY PRODUCTS FOR THE ELDERLY}

\section{Dairy Proteins and Sarcopenia}

Sarcopenia: The Condition. Sarcopenia is a condition characterized by a mainly chronic ongoing loss of muscle mass and muscle strength with advancing age (Cruz-Jentoft et al., 2019). It is therefore a condition of particular importance in the elderly (though not exclusively), with an increasing prevalence mainly associated with the increasing age of populations worldwide. Sarcopenia can have far-reaching consequences because, for example, it reduces bone protection, thus increasing the risk of breakage in a fall and leading to reduced mobility, disability, and lower quality of life. A lesser-known outcome of reduced muscle mass and possibly associated reduced exercise ability is the increased risk of metabolic diseases, type 2 diabetes in particular (Hunter et al., 2019).

Based on general population studies, Shafiee et al. (2017) published a meta-analysis on the prevalence of sarcopenia worldwide involving a total of 58,404 generally healthy subjects $>60 \mathrm{yr}$ of age. This study showed a mean prevalence of $10 \%$ in both men and women, with a higher value in non-Asian than Asian populations. The non-Asian values $(\sim 20 \%)$ were about double those of Asians when bioelectrical impedance analysis was used to estimate muscle mass.
Role of Dietary Proteins in Reducing Sarcopenia. Protein consumption and resistance exercise are both known to provide an anabolic stimulus for skeletal muscle protein synthesis, and there has been considerable debate about the amounts and the relative timing of protein consumption and exercise needed to stimulate muscle protein synthesis in the elderly. In the UK, the reference nutrient intake for protein is equivalent to $0.75 \mathrm{~g} / \mathrm{kg}$ of $\mathrm{BW}$, slightly less than the recommended dietary allowance (RDA) of $0.8 \mathrm{~g} / \mathrm{kg}$ of BW proposed for men and nonpregnant and nonlactating women $>18$ yr of age by FAO/WHO/UNU (2007). These recommendations take no account of specific age or health status. Lonnie et al. (2018) discussed and highlighted the relevance of new recommendations, suggesting protein requirements of 1.0 to $1.2,1.2$ to 1.5 , and $2.0 \mathrm{~g} / \mathrm{kg}$ of $\mathrm{BW}$ for people $>65 \mathrm{yr}$, those with acute or chronic illnesses, and those with severe illness or malnutrition, respectively. The review by Lonnie et al. (2018) cites work that confirms that intake of protein in accordance with the RDA has led to deleterious health outcomes, including a 14-wk RCT in subjects aged between 55 and $77 \mathrm{yr}$ who consumed the FAO/WHO/UNU (2007) RDA of $0.8 \mathrm{~g}$ of protein $/ \mathrm{kg}$ of BW, which led to a reduced mid-thigh muscle area and other characteristics suggesting that the protein intake was below requirements (Campbell et al., 2001). This is concerning because in the UK the latest National Diet and Nutrition Survey (Roberts et al., 2018) indicated a mean protein intake of $75.8 \mathrm{~g} / \mathrm{d}$ (men) and $60.5 \mathrm{~g} / \mathrm{d}$ (women) aged $65+\mathrm{yr}$, which with a mean BW for this age group of $85.8 \mathrm{~kg}$ (men) and $71.5 \mathrm{~kg}$ (women; National Statistics, $2017 \mathrm{~b}$ ) equates to 0.88 and $0.85 \mathrm{~g}$ of protein $/ \mathrm{kg}$ of BW for men and women, respectively.

Overall, there is considerable agreement about the benefits of the elderly increasing protein intake to 1.0 $\mathrm{g} / \mathrm{kg}$ of $\mathrm{BW}$ or higher, yet there have been concerns that the strong satiating effect of protein may limit total food and energy intake. In addition, there are concerns that higher protein intake may adversely affect individuals with chronic kidney disease that may be undiagnosed. The meta-analysis of Devries et al. (2018b) compared the effect of low-protein diets (mean $0.93 \mathrm{~g} /$ $\mathrm{kg}$ of BW per day) versus high-protein diets (mean 1.81 $\mathrm{g} / \mathrm{kg}$ of BW per day) and showed no effect on kidney function in subjects with normal function and in those with type 2 diabetes who would have a greater risk of chronic kidney disease. Nevertheless, it is probably wise for the elderly to have regular tests of kidney function irrespective of diet.

Type of Dietary Proteins for Reducing Sarcopenia. There has been considerable research on the relative anabolic effects of specific protein types. Wall et al. (2014) concluded that proteins such as whey 
protein that are rapidly digested and absorbed lead to greater muscle protein synthesis than proteins that are more slowly digested such as casein and those in soya. They also note that even when casein is hydrolyzed to increase digestion rate, the muscle protein response is still smaller than it is from equivalent amounts of whey protein. This is primarily attributed to the higher leucine content of whey protein; the specific effect of leucine was also seen in studies using leucine supplements (Wall et al., 2013; Devries et al., 2018a). The effect of leucine is complex. It is an important activator of the mammalian target of rapamycin, a nutrient-sensing signaling pathway in skeletal muscle. In addition, leucine is insulinotrophic, and the additional insulin enhances muscle protein synthesis (Paddon-Jones and Rasmussen, 2009). There is evidence however, that consumption of $40 \mathrm{~g}$ of casein before sleep increases muscle protein synthesis rates during overnight sleep in older men (Kouw et al., 2017). This is potentially important because overnight is generally a period of negative whole-body protein net balance.

Several studies have compared the relative value of plant proteins with that of whey protein. The study of Yang et al. (2012) compared the response of myofibrillar protein fractional synthetic rate in rested elderly men resulting from 0,20 , or $40 \mathrm{~g}$ of either whey protein or soya protein. Myofibrillar protein fractional synthetic rate did not respond to consumption of $40 \mathrm{~g}$ of soya protein compared with $20 \mathrm{~g}$, but it responded essentially in a linear fashion to increased whey protein. A similar differential effect was seen when the protein supplements were given postexercise.

Magnesium and Sarcopenia. As with the influence of magnesium intake on bone mineralization noted earlier, there is also increasing evidence of an association between magnesium and preservation of skeletal muscle. With a large cohort of 156,575 men and women aged 39 to 72 yr, Welch et al. (2017) examined crosssectional associations between magnesium intake and skeletal muscle mass (as fat-free mass percentage body mass, FFM\%) and grip strength. They showed positive associations between quintiles of magnesium intake and FFM\% $\left(P_{\text {trend }}<0.001\right)$ and grip strength $\left(P_{\text {trend }}<\right.$ $0.001)$. The association with grip strength was greater in older men (60 yr of age or older) than in younger men, although the opposite was the case for women.

Despite being a cross-sectional study, it was, according to the authors, the largest population to date used to study the association between magnesium intake and direct measures of skeletal muscle. Milk and milk products are important sources of magnesium, contributing some $13 \%$ to diets of the elderly (Roberts et al., 2018). In the US, it was reported that consuming the recommended quantities of dairy would significantly reduce the prevalence of low magnesium intake (Quann et al., 2015). Erem et al. (2019) highlighted that magnesium intake is particularly low in the elderly US population, which is similar to the UK, where $25 \%$ of individuals 75 yr old and above consume less than the lower reference nutrient intake. Clearly, more work on this is needed, but this study adds to increasing importance of magnesium in muscle and bone health.

\section{Dairy Foods and Bone Fragility}

Type of Dairy Foods. Unlike the situation with the young, the effect of dairy foods on bone strength in the elderly is less clear. A meta-analysis of 6 cohorts reported a $17 \%$ increased risk of hip fracture in men and women who consumed less than 1 glass of milk per day, although the change was not significant (Kanis et al., 2005). A later meta-analysis including a further 6 cohorts found no association between milk consumption and hip fracture risk (Bischoff-Ferrari et al., 2011). More recently, data from the Framingham Original Cohort (mean age at baseline $75 \mathrm{yr}$ ) showed that higher milk and milk + yogurt + cheese intakes were associated with higher lumber spine $\operatorname{BMD}(P=0.011$ and 0.005 , respectively) and higher milk + yogurt + cheese intakes protected against trochanter BMD loss $(P=$ 0.009 ) over $4 \mathrm{yr}$. In all cases, the significant beneficial associations were seen only in subjects who used vitamin D supplements (Sahni et al., 2017). The results from a Swedish female cohort indicated a significant 9\% increased risk of hip fracture per glass of milk per day $(P<0.05)$, whereas no effect was seen in a male cohort (Michaëlsson et al., 2014). The reasons for the positive associations in the women are unclear.

More recently, the analysis of 2 US cohorts containing 80,600 postmenopausal women and 43,306 men greater than $50 \mathrm{yr}$ of age at baseline who were followed up for 32 yr reported that for women and men combined, each serving of milk per day was associated with a $8 \%$ lower risk of hip fracture (RR: $0.92 ; 95 \%$ CI: 0.87-0.97) compared with those who consumed less than 1 serving per week (Feskanich et al., 2018). The authors suggested that a major strength of the study was that multiple measures of milk and dairy food intake were made over the $32 \mathrm{yr}$ of follow-up, allowing long-term mean intakes to be estimated. Calcium, vitamin D, and protein from nondairy and dairy sources did not influence the association between milk and fracture risk in this study, although a recent meta-analysis of 20 studies showed that a dietary pattern classified as "milk/dairy" led to the greatest reduction in risk of low BMD compared with patterns classified as "healthy" and "meat/Western"; the effect remained significant $(P<0.0001)$ in older women (Fabiani et al., 2019). 
Ong et al. (2020) conducted a systematic review on fermented milk products (yogurt and cheese) and bone health in postmenopausal women. The analysis included RCT, prospective cohorts, and case-control studies. Overall, only increased yogurt consumption was associated with a reduced risk of hip fracture compared with little or no intake. The evidence for cheese was limited and suggests that further work to understand the effect of yogurt is needed.

Magnesium and Bone Health. The possibly important role of dietary magnesium for bone development in young people was discussed earlier, but there is now some evidence of a similar benefit in later life. The review of Erem et al. (2019) highlights that the risk of osteoporosis in older people can result from low intake of magnesium, which gives rise to excess calcium release from bone and increased excretion, which increases bone fragility and hence the risk of bone fractures. Also, high intakes of calcium can lead to lower retention of magnesium. Erem et al. (2019) suggested that the optimal dietary ratio of calcium to magnesium is between 2.0:1.0 and 2.8:1.0, but in many current US diets the ratio is above 3.0:1.0.

There is an obvious need to further explore the role of magnesium and its interaction with calcium and vitamin D in relation to bone strength in the elderly. Dairy products are a good source of calcium and for many an important source of magnesium along with vitamin $\mathrm{D}$ when fortification is practiced.

\section{CONCLUSIONS}

Despite a favorable ongoing increase in life expectancy, an increase in healthy life span is not guaranteed; indeed, some of the health issues in aging populations arise because of longer life. Moreover, there is now increasing evidence that diets in early life can influence health in older life stages. There is good evidence that milk and dairy foods are important sources of nutrients, some of which are particularly important at certain life stages. The concentration of some nutrients, notably iodine, are also dependent on the diet of the milk-producing animal, a good example of an early stage in the food chain having an influence on nutrient intake. Reduced milk consumption in adolescent girls is a major worry because it may have already had an effect on bone development such that reduced bone strength may become evident when they are much older. Despite being counterintuitive to many, there is now consistent evidence that consumption of milk and dairy foods does not increase the risk of CMD. Indeed, several significant negative associations with risk of this group of diseases have been reported. The negative and positive associations of yogurt with type 2 diabetes and bone strength, respectively, are particularly interesting given the rapid rise in prevalence of type 2 diabetes and bone weakness; these should be researched with urgency to identify the mechanisms involved and to develop yogurt with targeted efficacy. Much greater effort is also needed to reduce malnutrition in the elderly and to reduce the loss of muscle mass, bone strength, and functionality, and this provides good opportunities for dairy products to play a key role. There is an ongoing debate about the relative sustainability of animal versus plant food sources. Although it makes sense to examine this tradeoff, it is important that judgements on the replacement of dairy products with those from plants include evidence on relative functionality (e.g., hypotensive and muscle protein synthesis stimulation effects) and not only simple comparisons of nutrient content (Grant and Hicks, 2018). Interestingly, a recent detailed modeling of the relationship between diet and health care costs concludes that adoption of a dietary pattern with increased dairy consumption by US adults would have the potential to save billions of dollars (Scrafford et al., 2020).

\section{ACKNOWLEDGMENTS}

This paper is based on an invited contribution to the symposium "Improving Milk Production, Quality, and Safety in Developing Countries" hosted by the Feed the Future Innovation Lab for Livestock Systems (FFILLS) of the University of Florida, at the ADSA Annual Meeting in Cincinnati, Ohio, on June 23-26, 2019. The author is grateful to Adegbola Adesogan, director of FFILLS, for his invitation. Travel to the meeting was funded by the American Dairy Science Association. The author has not stated any conflicts of interest.

\section{REFERENCES}

Abdullah, A., A. Peeters, M. de Courten, and J. Stoelwinder. 2010. The magnitude of association between overweight and obesity and the risk of diabetes: A meta-analysis of prospective cohort studies. Diabetes Res. Clin. Pract. 89:309-319. https://doi.org/10.1016/j diabres.2010.04.012.

Abrams, S. A., Z. Chen, and K. M. Hawthorne. 2014. Magnesium metabolism in 4-year-old to 8-year-old children. J. Bone Miner. Res. 29:118-122. https://doi.org/10.1002/jbmr.2021.

Astrup, A., H. C. S. Bertram, J.-P. Bonjour, L. C. P. de Groot, M. C. de Oliveira Otto, E. L. Feeney, M. L. Garg, D. I. Givens, F. J. Kok, R. M. Krauss, B. Lamarche, J.-M. Lecerf, P. Legrand, M. McKinley, R. Micha, M.-C. Michalski, D. Mozaffarian, and S. S. Soedamah-Muthu. 2019. WHO draft guidelines on dietary saturated and trans fatty acids: Time for a new approach? BMJ 366:14137. https://doi.org/10.1136/bmj.l4137.

Baker, I. A., P. C. Elwood, J. Hughes, M. Jones, F. Moore, and P. Sweetnam. 1980. A randomised controlled trial of the effect of the provision of free school milk on the growth of children. J. Epidemiol. Community Health 34:31-34. https://doi.org/10.1136/jech .34 .1 .31 . 
Bates, B., A. Lennox, A. Prentice, C. Bates, P. Page, S. Nicholson, and G. Swan. 2014. National Diet and Nutrition Survey, Results from Years 1-4 (combined) of the Rolling Programme (2008/2009 2011/12). Accessed Jul. 2020. https://assets.publishing.service.gov .uk/government/uploads/system/uploads/attachment_data/file/ 594361/NDNS_Y1_to_4_UK_report_full_text_revised_February 2017.pdf.

Bath, S. C., S. Button, and M. P. Rayman. 2012. Iodine concentration of organic and conventional milk: Implications for iodine intake. Br. J. Nutr. 107:935-940. https://doi.org/10.1017/ S0007114511003059.

Bath, S. C., S. Hill, H. G. Infante, S. Elghul, C. J. Nezianya, and M. P. Rayman. 2017. Iodine concentration of milk-alternative drinks available in the UK in comparison to cows' milk. Br. J. Nutr. 118:525-532. https://doi.org/10.1017/S0007114517002136.

Bath, S. C., and M. P. Rayman. 2015. A review of the iodine status of UK pregnant women and its implications for the offspring. Environ. Geochem. Health 37:619-629. https://doi.org/10.1007/s10653 -015-9682-3.

Bath, S. C., C. D. Steer, J. Golding, P. Emmett, and M. P. Rayman. 2013. Effect of inadequate iodine status in UK pregnant women on cognitive outcomes in their children: Results from the Avon Longitudinal Study of Parents and Children (ALSPAC). Lancet 382:331-337. https://doi.org/10.1016/S0140-6736(13)60436-5.

Bath, S. C., A. Walter, A. Taylor, J. Wright, and M. P. Rayman. 2014. Iodine deficiency in pregnant women living in the South East of the UK: The influence of diet and nutritional supplements on iodine status. Br. J. Nutr. 111:1622-1631. https://doi.org/10.1017/ S0007114513004030.

Batty, B. S., and M. Bionaz. 2019. Graduate Student Literature Review: The milk behind the moustache: A review of milk and bone biology. J. Dairy Sci. 102:7608-7617. https://doi.org/10.3168/jds .2019-16421.

Benjamin, E. J., S. S. Virani, C. W. Callaway, A. M. Chamberlain, A. R. Chang, S. Cheng, S. E. Chiuve, M. Cushman, F. N. Delling, R. Deo, S. D. de Ferranti, J. F. Ferguson, M. Fornage, C. Gillespie, C. R. Isasi, M. C. Jiménez, L. C. Jordan, S. E. Judd, D. Lackland, J. H. Lichtman, L. Lisabeth, S. Liu, C. T. Longenecker, P. L. Lutsey, J. S. Mackey, D. B. Matchar, K. Matsushita, M. E. Mussolino, K. Nasir, M. O'Flaherty, L. P. Palaniappan, A. Pandey, D. K. Pandey, M. J. Reeves, M. D. Ritchey, C. J. Rodriguez, G. A. Roth, W. D. Rosamond, U. K. A. Sampson, G. M. Satou, S. H. Shah, N. L. Spartano, D. L. Tirschwell, C. W. Tsao, J. H. Voeks, J. Z. Willey, J. T. Wilkins, J. H. Y. Wu, H. M. Alger, S. S. Wong, P. Muntner, and American Heart Association Council on Epidemiology and Prevention Statistics Committee and Stroke Statistics Subcommittee. 2018. Heart disease and stroke statistics - 2018 update: A report from the American Heart Association. Circulation 137:e67e492. https://doi.org/10.1161/CIR.0000000000000558.

Bischoff-Ferrari, H. A., B. Dawson-Hughes, J. A. Baron, J. A. Kanis, E. J. Orav, H. B. Staehelin, P. Kiel, P. Burckhardt, J. Henschkowski, D. Spiegelman, R. Li, J. B. Wong, D. Feskanich, and W. C. Willett. 2011. Milk intake and risk of hip fracture in men and women; a meta-analysis of prospective cohort studies. J. Bone Miner. Res. 26:833-839. https://doi.org/10.1002/jbmr.279.

Black, R. E., S. M. Williams, I. E. Jones, and A. Goulding. 2002. Children who avoid drinking cow milk have low dietary calcium intakes and poor bone health. Am. J. Clin. Nutr. 76:675-680. https://doi .org/10.1093/ajcn/76.3.675.

Bougma, K., F. E. Aboud, K. B. Harding, and G. S. Marquis. 2013. Iodine and mental development of children 5 years old and under: A systematic review and meta-analysis. Nutrients 5:1384-1416. https://doi.org/10.3390/nu5041384.

Brantsæter, A. L., M. H. Abel, M. Haugen, and H. M. Meltzer. 2013. Risk of suboptimal iodine intake in pregnant Norwegian women. Nutrients 5:424-440. https://doi.org/10.3390/nu5020424.

Businge, C. B., N. Madini, B. Longo-Mbenza, and A. P. Kengne. 2019. Insufficient iodine nutrition status and the risk of pre-eclampsia: A protocol for systematic review and meta-analysis. BMJ Open 9:e025573. https://doi.org/10.1136/bmjopen-2018-025573.
Campbell, W. W., T. A. Trappe, R. R. Wolfe, and W. J. Evans. 2001 The recommended dietary allowance for protein may not be adequate for older people to maintain skeletal muscle. J. Gerontol. A Biol. Sci. Med. Sci. 56:M373-M380. https://doi.org/10.1093/ gerona/56.6.M373.

Cashman, K. D., K. G. Dowling, Z. Skrabáková, M. Gonzalez-Gross, J. Valtueña, S. De Henauw, L. Moreno, C. T. Damsgaard, K. F. Michaelsen, C. Mølgaard, R. Jorde, G. Grimnes, G. Moschonis, C. Mavrogianni, Y. Manios, M. Thamm, G. B. M. Mensink, M. Rabenberg, M. A. Busch, L. Cox, S. Meadows, G. Goldberg, A. Prentice, J. M. Dekker, G. Nijpels, S. Pilz, K. M. Swart, N. M. van Schoor, P. Lips, G. Eiriksdottir, V. Gudnason, M. F. Cotch, S. Koskinen, C. Lamberg-Allardt, R. A. Durazo-Arvizu, C. T. Sempos, and M. Kiely. 2016. Vitamin D deficiency in Europe: Pandemic? Am. J. Clin. Nutr. 103:1033-1044. https://doi.org/10 .3945/ajcn.115.120873.

Chen, M., A. Pan, V. S. Malik, and F. B. Hu. 2012. Effects of dairy intake on body weight and fat: A meta-analysis of randomized controlled trials. Am. J. Clin. Nutr. 96:735-747.

Choudhury, S., and D. D. Headey. 2018. Household dairy production and child growth: Evidence from Bangladesh. Econ. Hum. Biol. 30:150-161. https://doi.org/10.1016/j.ehb.2018.07.001.

Cockcroft, J. R., and I. B. Wilkinson. 2000. Large arterial stiffness: An important therapeutic target. J. Hum. Hypertens. 14:533-535. https://doi.org/10.1038/sj.jhh.1001104.

Corry Mann, H. C. 1926. Diets for boys during the school age. Medical Research Council Special Report Series No. 105. HMSO, London, UK.

Costeira, M. J., P. Oliveira, N. C. Santos, S. Ares, B. Saenz-Rico, G. M. de Escobar, and J. A. Palha. 2011. Psychomotor development of children from iodine-deficient region. J. Pediatr. 159:447-453. https://doi.org/10.1016/j.jpeds.2011.02.034.

Crichton, G. E., M. F. Elias, G. A. Dore, A. P. Abhayaratna, and M. A. Robbins. 2012. Relations between dairy food intake and arterial stiffness. Hypertension 59:1044-1051. https://doi.org/10 .1161/HYPERTENSIONAHA.111.190017.

Cruz-Jentoft, A. J., G. Bahat, J. Bauer, Y. Boirie, O. Bruyère, T. Cederholm, C. Cooper, F. Landi, Y. Rolland, A. A. Sayer, S. M. Schneider, C. C. Sieber, E. Topinkova, M. Vandewoude, M. Visser, M. Zamboni, I. Bautmans, J.-P. Baeyens, M. Cesari, A. Cherubini, J. Kanis, M. Maggio, F. Martin, J.-P. Michel, K. Pitkala, J.-Y. Reginster, R. Rizzoli, D. Sánchez-Rodríguez, and J. Schols. 2019. Sarcopenia: Revised European consensus on definition and diagnosis. Age Ageing 48:16-31. https://doi.org/10.1093/ageing/afy169.

de Goede, J., S. S. Soedamah-Muthu, A. Pan, L. Gijsbers, and J. M. Geleijnse. 2016. Dairy consumption and risk of stroke: A systematic review and updated dose-response meta-analysis of prospective cohort studies. J. Am. Heart Assoc. 5:e002787. https://doi.org/10 $.1161 /$ JAHA.115.002787.

de Onis, M., and F. Branca. 2016. Childhood stunting: A global perspective. Matern. Child Nutr. 12(Suppl. 1):12-26. https://doi.org/ 10.1111/mcn.12231.

Dehghan, M., A. Mente, S. Rangarajan, P. Sheridan, V. Mohan, R. Iqbal, R. Gupta, S. Lear, E. Wentzel-Viljoen, A. Avezum, P. Lopez-Jaramillo, P. Mony, R. P. Varma, R. Kumar, J. Chifamba, K. F. Alhabib, N. Mohammadifard, A. Oguz, F. Lanas, D. Rozanska, K. B. Bostrom, K. Yusoff, L. P. Tsolkile, A. Dans, A. Yusufali, A. Orlandini, P. Poirier, R. Khatib, B. Hu, L. Wei, L. Yin, A. Deeraili, K. Yeates, R. Yusuf, N. Ismail, D. Mozaffarian, K. Teo, and S. S. Anand, and Prospective Urban Rural Epidemiology (PURE) study investigators. 2018. Association of dairy intake with cardiovascular disease and mortality in 21 countries from five continents (PURE): A prospective cohort study. Lancet 392:2288-2297. https://doi.org/10.1016/S0140-6736(18)31812-9.

Department of Health. 1991. Dietary Reference Values, a Guide. HMSO, London, UK.

Devries, M. C., C. McGlory, D. R. Bolster, A. Kamil, M. Rahn, L. Harkness, S. K. Baker, and S. M. Phillips. 2018a. Leucine, not total protein, content of a supplement is the primary determinant of muscle protein anabolic responses in healthy older women. J. Nutr. 148:1088-1095. https://doi.org/10.1093/jn/nxy091. 
Devries, M. C., A. Sithamparapillai, K. S. Brimble, L. Banfield, R. W. Morton, and S. M. Phillips. 2018b. Changes in kidney function do not differ between healthy adults consuming higher compared with lower- or normal-protein diets: A systematic review and meta-analysis. J. Nutr. 148:1760-1775. https://doi.org/10.1093/jn/ nxy197.

Diabetes UK. 2019. Number of people with diabetes reaches 4.7 million. Accessed Feb. 18, 2020. https://www.diabetes.org.uk/about _us/news/new-stats-people-living-with-diabetes.

Dougkas, A., S. Barr, S. Reddy, and C. D. Summerbell. 2019. A critical review of the role of milk and other dairy products in the development of obesity in children and adolescents. Nutr. Res. Rev. 32:106-127. https://doi.org/10.1017/S0954422418000227.

Dougkas, A., C. K. Reynolds, D. I. Givens, P. C. Elwood, and A. M. Minihane. 2011. Associations between dairy consumption and body weight: A review of the evidence and underlying mechanisms. Nutr. Res. Rev. 24:72-95.

Du, X., K. Zhu, A. Trube, Q. Zhang, G. Ma, X. Hu, D. R. Fraser, and H. Greenfield. 2004. School-milk intervention trial enhances growth and bone mineral accretion in Chinese girls aged 10-12 years in Beijing. Br. J. Nutr. 92:159-168. https://doi.org/10.1079/ BJN20041118.

Erem, S., A. Atfi, and M. S. Razzaque. 2019. Anabolic effects of vitamin D and magnesium in aging bone. J. Steroid Biochem. Mol. Biol. 193:105400. https://doi.org/10.1016/j.jsbmb.2019.105400.

European Commission. 2005. Council Regulation (EC) No 1459/2005 of 08 September 2005 amending the condition of authorization of a number of feed additives belonging to the group of trace elements. Off. J. L233:8-10.

Fabiani, R., G. Naldini, and M. Chiavarini. 2019. Dietary patterns in relation to low bone mineral density and fracture risk: A systematic review and meta-analysis. Adv. Nutr. 10:219-236. https://doi .org/10.1093/advances/nmy073.

FAO/WHO/UNU. 2007. Protein and amino acid requirements in human nutrition. Report of a joint $\mathrm{FAO} / \mathrm{WHO} / \mathrm{UNU}$ expert consultation. WHO Technical Report Series 935. World Health Organization, Geneva, Switzerland.

Feeney, E. L., R. Barron, V. Dible, Z. Hamilton, Y. Power, L. Tanner, C. Flynn, P. Bouchier, T. Beresford, N. Noronha, and E. R. Gibney. 2018. Dairy matrix effects: Response to consumption of dairy fat differs when eaten within the cheese matrix - A randomized controlled trial. Am. J. Clin. Nutr. 108:667-674. https://doi.org/ 10.1093/ajcn/nqy146.

Fekete, Á. A., C. Giromini, Y. Chatzidiakou, D. I. Givens, and J. A. Lovegrove. 2016. Whey protein lowers blood pressure and improves endothelial function and lipid biomarkers in adults with prehypertension and mild hypertension: Results from the chronic Whey2Go randomized controlled trial. Am. J. Clin. Nutr. 104:1534-1554. https://doi.org/10.3945/ajcn.116.137919.

Fekete, Á. A., C. Giromini, Y. Chatzidiakou, D. I. Givens, and J. A. Lovegrove. 2018. Whey protein lowers systolic blood pressure and Ca-caseinate reduces serum TAG after a high-fat meal in mildly hypertensive adults. Sci. Rep. 8:5026. https://doi.org/10.1038/ s41598-018-23333-2.

Fekete, Á. A., D. I. Givens, and J. A. Lovegrove. 2013. The impact of milk proteins and peptides on blood pressure and vascular function: A review of evidence from human intervention studies. Nutr. Res. Rev. 26:177-190. https://doi.org/10.1017/S0954422413000139.

Feskanich, D., H. A. Bischoff-Ferrari, L. Frazier, and W. C. Willett. 2014. Milk consumption during teenage years and risk of hip fractures in older adults. JAMA Pediatr. 168:54-60. https://doi.org/ 10.1001/jamapediatrics.2013.3821.

Feskanich, D., H. E. Meyer, T. T. Fung, H. A. Bischoff-Ferrari, and W. C. Willett. 2018. Milk and other dairy foods and risk of hip fracture in men and women. Osteoporos. Int. 29:385-396. https:// doi.org/10.1007/s00198-017-4285-8.

Figueroa, A., A. Wong, A. Kinsey, R. Kalfon, W. Eddy, and M. J. Ormsbee. 2014. Effects of milk proteins and combined exercise training on aortic hemodynamics and arterial stiffness in young obese women with high blood pressure. Am. J. Hypertens. 27:338344. https://doi.org/10.1093/ajh/hpt224.
FitzGerald, R. J., and H. Meisel. 2000. Milk protein-derived peptide inhibitors of angiotensin-1-converting enzyme. Br. J. Nutr. 84(Suppl. 1):S33-S37. https://doi.org/10.1017/S0007114500002221.

Flachowsky, G., K. Franke, U. Meyer, M. Leiterer, and F. Schöne. 2014. Influencing factors on iodine content of cow milk. Eur. J. Nutr. 53:351-365. https://doi.org/10.1007/s00394-013-0597-4.

Food Standards Agency. 2008. Retail Survey of Iodine in UK Produced Dairy Foods, FSIS 02/08. Food Standards Agency, London, UK.

Forbes, E. E., and R. E. Dahl. 2010. Pubertal development and behavior: Hormonal activation of social and motivational tendencies. Brain Cogn. 72:66-72. https://doi.org/10.1016/j.bandc.2009 .10 .007 .

Fourreau, D., N. Peretti, B. Hengy, Y. Gillet, S. Courtil-Teyssedre, L. Hess, I. Loras-Duclaux, N. Caron, C. Didier, F. Cour-Andlauer, S. Heissat, A. Lachaux, and É. Javouhey. 2013. Complications carentielles suite à l'utilisation de laits végéaux, chez des nourrissons de deux mois et demi à 14 mois (quatre cas). Presse Med. 42:e37-e43. https://doi.org/10.1016/j.lpm.2012.05.029.

Gatineau, M., C. Hancock, N. Holman, H. Outhwaite, L. Oldridge, C. Anna, and L. Ells. 2014. Adult Obesity and Type 2 diabetes. Public Health England, London, UK. https://assets.publishing.service .gov.uk/government/uploads/system/uploads/attachment_data/ file/338934/Adult_obesity_and_type_2_diabetes_.pdf.

Gijsbers, L., E. L. Ding, V. S. Malik, J. de Goede, J. M. Geleijnse, and S. S. Soedamah-Muthu. 2016. Consumption of dairy foods and diabetes incidence: A dose-response meta-analysis of observational studies. Am. J. Clin. Nutr. 103:1111-1124. https://doi.org/ 10.3945/ajcn.115.123216.

Giromini, C., Á. A. Fekete, D. I. Givens, A. Baldi, and J. A. Lovegrove. 2017. Short communication: A comparison of the in vitro angiotensin-converting enzyme inhibitory capacity of dairy and plant protein supplements. Nutrients 9:1352. https://doi.org/10 $.3390 /$ nu9121352.

Giromini, C., J. A. Lovegrove, D. I. Givens, R. Rebucci, L. Pinotti, E. Maffioli, G. Tedeschi, T. S. Sundaram, and A. Baldi. 2019. In vitro digested milk proteins: Evaluation of angiotensin-converting enzyme inhibitory and antioxidant activities, peptidomic profile and mucin gene expression in HT29-MTX cells. J. Dairy Sci. 102:10760-10771. https://doi.org/10.3168/jds.2019-16833.

Goldacre, M., N. Hall, and D. G. R. Yeates. 2014. Hospitalisation for children with rickets in England: A historical perspective. Lancet 383:597-598. https://doi.org/10.1016/S0140-6736(14)60211-7.

Grant, C. A., and A. L. Hicks. 2018. Comparative life cycle assessment of milk and plant-based alternatives. Environ. Eng. Sci. 35:12351247. https://doi.org/10.1089/ees.2018.0233.

Griffin, B. A., and J. A. Lovegrove. 2018. Butter increases HDL functional capacity: Is this compensation for its adverse effect on serum LDL cholesterol? J. Nutr. 148:1069-1070.

Gullberg, B., O. Johnell, and J. A. Kanis. 1997. World-wide projections for hip fracture. Osteoporos. Int. 7:407-413. https://doi.org/ 10.1007/PL00004148.

Guo, J., A. Astrup, J. A. Lovegrove, L. Gijsbers, D. I. Givens, and S. S. Soedamah-Muthu. 2017. Milk and dairy consumption and risk of cardiovascular diseases and all-cause mortality: Dose-response meta-analysis of prospective cohort studies. Eur. J. Epidemiol. 32:269-287. https://doi.org/10.1007/s10654-017-0243-1.

Guo, J., A. Dougkas, P. C. Elwood, and D. I. Givens. 2018. Dairy foods and body mass index over 10-year: Evidence from the Caerphilly Prospective Cohort Study. Nutrients 10:1515. https://doi .org/10.3390/nu10101515.

Guo, J., D. I. Givens, A. Astrup, S. J. L. Bakker, G. H. Goossens, M. Kratz, A. Marette, H. Pijl, and S. S. Soedamah-Muthu. 2019. The impact of dairy products in the development of type 2 diabetes: Where does the evidence stand in 2019? Adv. Nutr. 10:1066-1075. https://doi.org/10.1093/advances/nmz050.

Hernlund, E., A. Svedbom, M. Ivergård, J. Compston, C. Cooper, J. Stenmark, E. V. McCloskey, B. Jönsson, and J. A. Kanis. 2013 Osteoporosis in the European Union: Medical management, epidemiology and economic burden. Arch. Osteoporos. 8:136. https:// doi.org/10.1007/s11657-013-0136-1. 
Hjerpsted, J., E. Leedo, and T. Tholstrup. 2011. Cheese intake in large amounts lowers LDL-cholesterol concentrations compared with butter intake of equal fat content. Am. J. Clin. Nutr. 94:14791484. https://doi.org/10.3945/ajcn.111.022426.

Holick, M. F. 2010. The vitamin D deficiency pandemic: A forgotten hormone important for life. Public Health Rev. 32:267-283. https: //doi.org/10.1007/BF03391602.

Hoppe, C., C. Mølgaard, C. Dalum, A. Vaag, and K. F. Michaelsen. 2009. Differential effects of casein versus whey on fasting plasma levels of insulin, IGF-1 and IGF-1/IGFBP-3: Results from a randomized 7-day supplementation study in pre-pubertal boys. Eur. J. Clin. Nutr. 63:1076-1083. https://doi.org/10.1038/ejcn.2009.34.

Host, A., and S. Halken. 2014. Cow's milk allergy: Where have we come from and where are we going? Endocr. Metab. Immune Disord. Drug Targets 14:2-8. https://doi.org/10.2174/ 1871530314666140121142900.

Hu, F. B., J. E. Manson, M. J. Stampfer, G. Colditz, S. Liu, C. G. Solomon, and W. C. Willett. 2001. Diet, lifestyle and the rise of type 2 diabetes in women. N. Engl. J. Med. 345:790-797. https:// doi.org/10.1056/NEJMoa010492.

Hunter, G. R., H. Singh, S. J. Carter, D. R. Bryan, and G. Fisher. 2019. Sarcopenia and its implications for metabolic health. J. Obes. 2019:8031705. https://doi.org/10.1155/2019/8031705.

Hynes, K. L., P. Otahal, I. Hay, and J. R. Burgess. 2013. Mild iodine deficiency during pregnancy is associated with reduced educational outcomes in the offspring: 9-year follow-up of the gestational iodine cohort. J. Clin. Endocrinol. Metab. 98:1954-1962. https://doi.org/10.1210/jc.2012-4249.

Iguacel, I., M. L. Miguel-Berges, A. Gómez-Bruton, L. A. Moreno, and C. Julián. 2019. Veganism, vegetarianism, bone mineral density, and fracture risk: A systematic review and meta-analysis. Nutr. Rev. 77:1-18. https://doi.org/10.1093/nutrit/nuy045.

Itkonen, S. T., M. Erkkola, and C. J. E. Lamberg-Allardt. 2018. Vitamin D fortification of fluid milk products and their contribution to vitamin D intake and vitamin D status in observational studiesA review. Nutrients 10:1054. https://doi.org/10.3390/nu10081054.

Jazayeri, M., Y. Moradi, A. Rasti, M. Nakhjavani, M. Kamali, and H. R. Baradaran. 2018. Prevalence of vitamin D deficiency in healthy Iranian children: A systematic review and meta-analysis. Med. J. Islam Repub. 32:83. https://doi.org/10.14196/mjiri.32.83.

Kalkwarf, H. J., J. C. Khoury, and B. P. Lanphear. 2003. Milk intake during childhood and adolescence, adult bone density, and osteoporotic fractures in US women. Am. J. Clin. Nutr. 77:257-265. https://doi.org/10.1093/ajcn/77.1.257.

Kang, K., O. F. Sotunde, and H. A. Weiler. 2019. Effects of milk and milk product consumption on growth among children and adolescents aged 6-18 years: A meta-analysis of randomized controlled trials. Adv. Nutr. 10:250-261. https://doi.org/10.1093/advances/ nmy081.

Kanis, J. A., H. Johansson, A. Oden, C. De Laet, O. Johnell, J. A. Eisman, E. McCloskey, D. Mellstrom, H. Pols, J. Reeve, A. Silman, and A. A. Tenenhouse. 2005. Meta-analysis of milk intake and fracture risk: Low utility for case finding. Osteoporos. Int. 16:799-804. https://doi.org/10.1007/s00198-004-1755-6.

Kouw, I. W. K., A. M. Holwerda, J. Trommelen, I. F. Kramer, J. Bastiaanse, S. L. Halson, W. K. W. H. Wodzig, L. B. Verdijk, and L. J. C. van Loon. 2017. Protein ingestion before sleep increases overnight muscle protein synthesis rates in healthy older men: A randomized controlled trial. J. Nutr. 147:2252-2261. https://doi .org/10.3945/jn.117.254532.

Kratz, M., T. Baars, and S. Guyenet. 2013. The relationship between high-fat dairy consumption and obesity, cardiovascular, and metabolic disease. Eur. J. Nutr. 52:1-24. https://doi.org/10.1007/ s00394-012-0418-1.

Kris-Etherton, P. M., J. A. Grieger, H. F. Hilpert, and S. G. West. 2009. Milk products, dietary patterns and blood pressure management. J. Am. Coll. Nutr. 28(Suppl. 1):103S-119S. https://doi.org/ 10.1080/07315724.2009.10719804.

Kunutsor, S. K., M. R. Whitehouse, A. W. Blom, and J. A. Laukkanen. 2017. Low serum magnesium levels are associated with in- creased risk of fractures: A long-term prospective cohort study. Eur. J. Epidemiol. 32:593-603. https://doi.org/10.1007/s10654 $-017-0242-2$

Larson, N. I., D. Neumark-Sztainer, L. Harnack, M. Wall, M. Story, and M. E. Eisenberg. 2009. Calcium and dairy intake: Longitudinal trends during the transition to young adulthood and correlates of calcium intake. J. Nutr. Educ. Behav. 41:254-260. https://doi .org/10.1016/j.jneb.2008.05.001.

Le Louer, B., J. Lemale, K. Garcette, C. Orzechowski, A. Chalvon, J.-P. Girardet, and P. Tounian. 2014. Conséquences nutritionnelles de l'utilisation de boissons végétales inadaptées chez les nourrissons de moins d'un an. Arch. Pediatr. 21:483-488. https://doi.org/ 10.1016/j.arcped.2014.02.027.

Lee, K. W., D. Shin, M. S. Cho, and W. O. Song. 2016. Food group intakes as determinants of iodine status among us adult population. Nutrients 8:325. https://doi.org/10.3390/nu8060325.

Leroy, J. L., and E. A. Frongillo. 2019. Perspective: What does stunting really mean? A critical review of the evidence. Adv. Nutr. 10:196-204. https://doi.org/10.1093/advances/nmy101.

Livingstone, K. M., J. A. Lovegrove, J. R. Cockcroft, P. C. Elwood, J. E. Pickering, and D. I. Givens. 2013. Does dairy food intake predict arterial stiffness and blood pressure in men? Evidence from the Caerphilly Prospective Study. Hypertension 61:42-47. https:// doi.org/10.1161/HYPERTENSIONAHA.111.00026.

Locatelli, V., and V. E. Bianchi. 2014. Effect of GH/IGF-1 on bone metabolism and osteoporosis. Int. J. Endocrinol. 2014:235060. https://doi.org/10.1155/2014/235060.

Lonnie, M., E. Hooker, J. M. Brunstrom, B. M. Corfe, M. A. Green, A. W. Watson, E. A. Williams, E. J. Stevenson, S. Penson, and A. M. Johnstone. 2018. Protein for life: Review of optimal protein intake, sustainable dietary sources and the effect on appetite in ageing adults. Nutrients 10:360. https://doi.org/10.3390/nu10030360.

Lu, L., P. Xun, Y. Wan, K. He, and W. Cai. 2016. Long-term association between dairy consumption and risk of childhood obesity: A systematic review and meta-analysis of prospective cohort studies. Eur. J. Clin. Nutr. 70:414-423. https://doi.org/10.1038/ejen.2015 .226 .

Ma, X. M., Z. Huang, X. Yang, and Y. Su. 2014. Calcium supplementation and bone mineral accretion in Chinese adolescents aged 12-14 years: A 12-month, dose-response, randomised intervention trial. Br. J. Nutr. 112:1510-1520. https://doi.org/10.1017/ S0007114514002384.

Michaelsen, K. F. 2013. Cow's milk in the prevention and treatment of stunting and wasting. Food Nutr. Bull. 34:249-251. https://doi .org $/ 10.1177 / 156482651303400219$

Michaëlsson, K., A. Wolk, S. Langenskiöld, S. Basu, E. Warensjo Lemming, H. Melhus, and L. Byberg. 2014. Milk intake and risk of mortality and fractures in women and men: Cohort studies. BMJ 349:g6015. https://doi.org/10.1136/bmj.g6015.

Miles, E. A. 2020. Adverse reactions to cow's milk. Pages 271-297 in Milk and Dairy Foods: Their Functionality in Human Health and Disease. D. I. Givens, ed. Elsevier, Cambridge, MA.

Mtumwa, A. H., J. E. Ntwenya, E. Paul, M. Huang, and S. Vuai. 2017. Socio-economic and spatial correlates of subclinical iodine deficiency among pregnant women age $15-49$ years in Tanzania. BMC Nutr. 3:47. https://doi.org/10.1186/s40795-017-0163-1.

Mullan, K., L. Hamill, K. Doolan, I. Young, P. Smyth, A. Flynn, J. Walton, A. A. Meharg, M. Carey, C. McKernan, M. Bell, N. Black, U. Graham, D. McCance, C. McHugh, P. McMullan, S. McQuaid, A. O'Loughlin, A. Tuthill, S. C. Bath, M. Rayman, and J. V. Woodside. 2020. Iodine status of teenage girls on the island of Ireland. Eur. J. Nutr. 59:1859-1867. https://doi.org/10.1007/ s00394-019-02037-x.

Munblit, D., M. R. Perkin, D. J. Palmer, K. J. Allen, and R. J. Boyle. 2020. Assessment of evidence about common infant symptoms and cow's milk allergy. JAMA Pediatr. 174:599-608. https://doi.org/ 10.1001/jamapediatrics.2020.0153.

National Statistics. 2017a. Health Survey for England 2016, summary of key findings. Accessed Dec. 12, 2019. https://files.digital.nhs .uk/pdf/s/q/hse2016-summary.pdf. 
National Statistics. 2017b. Health Survey for England 2016, adult health trends. Accessed Dec. 12, 2019. http://healthsurvey.hscic .gov.uk/media/63757/HSE2016-Adult-trends.pdf.

NHS. 2019. Stages of puberty. Accessed Jan. 15, 2020. https://www .nhs.uk/live-well/sexual-health/stages-of-puberty-what-happens -to-boys-and-girls/.

Nittari, G., S. Scuri, F. Petrelli, I. Pirillo, N. M. di Luca, and I. Grappasonni. 2019. Fighting obesity in children from European World Health Organization member states. Epidemiological data, medical-social aspects, and prevention programs. Clin. Ter. 170:e223-e230. http://www.clinicaterapeutica.it/ojs/index.php/ ClinicaTerapeutica/article/view/427/169.

O'Brien, B., D. Gleeson, and K. Jordan. 2013. Iodine concentrations in milk. Ir. J. Agric. Food Res. 52:209-216.

O'Kane, S. M., L. K. Pourshahidi, M. S. Mulhern, J. J. Strain, E. M. Mackle, D. Koca, L. Schomburg, S. Hill, J. O'Reilly, D. Kmiotek, C. Deitrich, S. C. Bath, and A. J. Yeates. 2018. Cow milk consumption increases iodine status in women of childbearing age in a randomized controlled trial. J. Nutr. 148:401-408. https://doi.org/ $10.1093 /$ jn $/$ nxx043.

OECD (Organisation for Economic Co-operation and Development). 2017. Obesity update. Accessed Dec. 12, 2019. www.oecd.org/ health/obesity-update.htm.

Ong, A. M., K. Kang, H. A. Weiler, and S. N. Morin. 2020. Fermented milk products and bone health in postmenopausal women: A systematic review of randomized controlled trials, prospective cohorts, and case-control studies. Adv. Nutr. 11:251-265. https:// doi.org/10.1093/advances/nmz108.

Paddon-Jones, D., and B. B. Rasmussen. 2009. Dietary protein recommendations and the prevention of sarcopenia. Curr. Opin. Clin. Nutr. Metab. Care 12:86-90. https://doi.org/10.1097/MCO $.0 \mathrm{~b} 013 \mathrm{e} 32831 \mathrm{cef} 8 \mathrm{~b}$

Pastuszka, R., J. Barłowska, and Z. Litwińczuk. 2016. Allergenicity of milk of different animal species in relation to human milk. Postepy Hig. Med. Dosw. (Online) 70:1451-1459. https://doi.org/10.5604/ 17322693.1227842 .

Payling, L. M., D. T. Juniper, C. Drake, C. Rymer, and D. I. Givens. 2015. Effect of milk type and processing on iodine concentration of organic and conventional winter milk at retail: Implications for nutrition. Food Chem. 178:327-330. https://doi.org/10.1016/j .foodchem.2015.01.091.

Pimpin, L., J. H. Y. Wu, H. Haskelberg, L. Del Gobbo, and D. Mozaffarian. 2016. Is butter back? A systematic review and metaanalysis of butter consumption and risk of cardiovascular disease, diabetes, and total mortality. PLoS One 11:e0158118. https://doi .org/10.1371/journal.pone.0158118.

Prentice, A. 2013. Nutritional rickets around the world. J. Steroid Biochem. Mol. Biol. 136:201-206. https://doi.org/10.1016/j.jsbmb .2012.11.018.

Quann, E. E., V. L. Fulgoni III, and N. Auestad. 2015. Consuming the daily recommended amounts of dairy products would reduce the prevalence of inadequate micronutrient intakes in the United States: Diet modeling study based on NHANES 2007-2010. Nutr. J. 14:90. https://doi.org/10.1186/s12937-015-0057-5.

Rangel, A. H. N., D. C. Sales, S. A. Urbano, J. G. B. Galvão Júnior, J. C. de Andrade Neto, and C. S. Macêdo. 2016. Lactose intolerance and cow's milk protein allergy. Food Sci. Technol. (Campinas) 36. https://doi.org/10.1590/1678-457X.0019.

Roberts, C., T. Steer, N. Maplethorpe, L. Cox, S. Meadows, S. Nicholson, P. Page, and G. Swan. 2018. National Diet and Nutrition Survey. Results from Years 7-8 (combined) of the Rolling Programme (2014/15 to 2015/16). PHE Publication gateway number 2017851. Public Health England, London, UK.

Roser, M. 2017. Life expectancy. Accessed Jun. 5, 2017. https:// ourworldindata.org/life-expectancy/.

Rosqvist, F., A. Smedman, H. Lindmark-Mansson, M. Paulsson, P. Petrus, S. Straniero, M. Rudling, I. Dahlman, and U. Risérus. 2015. Potential role of milk fat globule membrane in modulating plasma lipoproteins, gene expression, and cholesterol metabolism in humans: A randomized study. Am. J. Clin. Nutr. 102:20-30. https://doi.org/10.3945/ajcn.115.107045.
Sahni, S., K. M. Mangano, D. P. Kiel, K. I. Tucker, and M. T. Hannan. 2017. Dairy intake is protective against bone loss in older vitamin D supplement users: The Framingham Study. J. Nutr. 147:645-652. https://doi.org/10.3945/jn.116.240390.

Scholz-Ahrens, K. E., F. Ahrens, and C. A. Barth. 2020. Nutritional and health attributes of milk and milk imitations. Eur. J. Clin. Nutr. 59:19-34. https://doi.org/10.1007/s00394-019-01936-3.

Scrafford, C. G., X. Bi, J. K. Multani, M. M. Murphy, J. K. Schmier, and L. M. Barraj. 2020. Health care costs and savings associated with increased dairy consumption among adults in the United States. Nutrients 12:233. https://doi.org/10.3390/nu12010233.

Semali, I. A., A. Tengia-Kessy, E. J. Mmbaga, and G. Leyna. 2015. Prevalence and determinants of stunting in under-five children in central Tanzania: Remaining threats to achieving Millennium Development Goal 4. BMC Public Health 15:1153. https://doi.org/ 10.1186/s12889-015-2507-6 https://dx.doi.org/10.1186\%2Fs12889 $-015-2507-6$

Shafiee, G., A. Keshtkar, A. Soltani, Z. Ahadi, B. Larijani, and R. Heshmat. 2017. Prevalence of sarcopenia in the world: A systematic review and meta-analysis of general population studies. J. Diabetes Metab. Dis. 16:21. https://doi.org/10.1186/s40200-017-0302-x.

Soedamah-Muthu, S. S., and J. de Goede. 2018. Dairy consumption and cardiometabolic diseases: Systematic review and updated meta-analyses of prospective cohort studies. Curr. Nutr. Rep. 7:171182. https://doi.org/10.1007/s13668-018-0253-y.

Średnicka-Tober, D., M. Barański, C. J. Seal, R. Sanderson, C. Benbrook, H. Steinshamn, J. Gromadzka-Ostrowska, E. Rembiałkowska, K. Skwarło-Sońta, M. Eyre, G. Cozzi, M. K. Larsen, T. Jordon, U. Niggli, T. Sakowski, P. C. Calder, G. C. Burdge, S. Sotiraki, A. Stefanakis, S. Stergiadis, H. Yolcu, E. Chatzidimitriou, G. Butler, G. Stewart, and C. Leifert. 2016. Higher PUFA and n-3 PUFA, conjugated linoleic acid, $\alpha$-tocopherol and iron, but lower iodine and selenium concentrations in organic milk: A systematic literature review and meta- and redundancy analyses. Br. J. Nutr. 115:1043-1060. https://doi.org/10.1017/S0007114516000349.

Steinberger, J., S. R. Daniels, N. Hagberg, C. R. Isasi, A. S. Kelly, D. Lloyd-Jones, R. R. Pate, C. Pratt, C. M. Shay, J. A. Towbin, E. Urbina, L. V. Van Horn, and J. P. Zachariah. 2016. Cardiovascular health promotion in children: Challenges and opportunities for 2020 and beyond. Circulation 134:e236-e255. https://doi.org/10 $.1161 /$ CIR.0000000000000441.

Stevenson, M. C., C. Drake, and D. I. Givens. 2018. Further studies on the iodine concentration of conventional, organic and UHT semiskimmed milk at retail in the UK. Food Chem. 239:551-555. https: //doi.org/10.1016/j.foodchem.2017.06.135.

Thacher, T. D., P. R. Fischer, P. J. Tebben, R. J. Singh, S. S. Cha, J. A. Maxson, and B. P. Yawn. 2013. Increasing incidence of nutritional rickets: A population-based study in Olmsted County, Minnesota. Mayo Clin. Proc. 88:176-183. https://doi.org/10.1016/ j.mayocp. 2012.10.018.

Thorning, T. K., H. C. Bertram, J.-P. Bonjour, L. de Groot, D. Dupont, E. Feeney, R. Ipsen, J.-M. Lecerf, A. Mackie, M. C. McKinley, M.-C. Michalski, D. Rémond, U. Risérus, S. Soedamah-Muthu, T. Tholstrup, C. Weaver, A. Astrup, and D. I. Givens. 2017. Whole dairy matrix or single nutrients in assessment of health effects: Current evidence and knowledge gaps. Am. J. Clin. Nutr. 105:1033-1045. https://doi.org/10.3945/ajcn.116.151548.

Totzauer, M., V. Luque, J. Escribano, R. Closa-Monasterolo, E. Verduci, A. ReDionigi, J. Hoyos, J.-P. Langhendries, D. Gruszfeld, P. Socha, B. Koletzko, V. Grote, and European Childhood Obesity Trial Study Group. 2018. Effect of lower versus higher protein content in infant formula through the first year on body composition from 1 to 6 years: Follow-up of a randomized clinical trial. Obesity (Silver Spring) 26:1203-1210. https://doi.org/10.1002/oby.22203.

Turner, P. J., M. H. Gowland, V. Sharma, D. Ierodiakonou, N. Harper, T. Garcez, R. Pumphrey, and R. J. Boyle. 2015. Increase in anaphylaxis-related hospitalizations but no increase in fatalities: An analysis of United Kingdom national anaphylaxis data, 1992-2012. J. Allergy Clin. Immunol. 135:956-963. https://doi.org/10.1016/j .jaci.2014.10.021 
van Mil, N. H., H. Tiemeier, J. J. Bongers-Schokking, A. Ghassabian, A. Hofman, H. Hooijkaas, V. W. V. Jaddoe, S. M. de Muinck Keizer-Schrama, E. A. P. Steegers, T. J. Visser, W. Visser, H. A. Ross, F. C. Verhulst, Y. B. de Rijke, and R. P. M. Steegers-Theunissen. 2012. Low urinary iodine excretion during early pregnancy is associated with alterations in executive functioning in children. J. Nutr. 142:2167-2174. https://doi.org/10.3945/jn.112.161950.

Vanderpump, M. P. J., J. H. Lazarus, P. P. Smyth, P. Laurberg, R. L. Holder, K. Boelaert, and J. A. Franklyn. 2011. Iodine status of UK schoolgirls: A cross-sectional survey. Lancet 377:2007-2012. https: //doi.org/10.1016/S0140-6736(11)60693-4.

Vojdani, A., C. Turnpaugh, and E. Vojdani. 2018. Immune reactivity against a variety of mammalian milks and plant-based milk substitutes. J. Dairy Res. 85:358-365. https://doi.org/10.1017/ S0022029918000523.

Wall, B. T., H. Hamer, A. de Lange, A. Kiskini, B. B. Groen, J. M. Senden, A. P. Gijsen, L. B. Verdijk, and L. J. van Loon. 2013. Leucine co-ingestion improves post-prandial muscle protein accretion in elderly men. Clin. Nutr. 32:412-419. https://doi.org/10.1016/j .clnu.2012.09.002.

Wall, B. T., N. M. Cermak, and L. J. C. van Loon. 2014. Dietary protein considerations to support active aging. Sports Med. 44(Suppl. 2):185-194. https://doi.org/10.1007/s40279-014-0258-7.

Wan, X., S. Wang, J. Xu, L. Zhuang, K. Xing, M. Zhang, X. Zhu, L. Wang, P. Gao, Q. Xi, J. Sun, Y. Zhang, T. Li, G. Shu, and Q. Jiang. 2017. Dietary protein-induced hepatic IGF-1 secretion mediated by PPAR $\gamma$ activation. PLoS One 12:e0173174. https://doi .org/10.1371/journal.pone.0173174.

Weaver, C. M., C. M. Gordon, K. F. Janz, H. J. Kalkwarf, J. M. Lappe, R. Lewis, M. O'Karma, T. C. Wallace, and B. S. Zemel. 2016. The National Osteoporosis Foundation's position statement on peak bone mass development and lifestyle factors: A systematic review and implementation recommendations. Osteoporos. Int. 27:1281-1386. https://doi.org/10.1007/s00198-015-3440-3.

Welch, A. A., J. Skinner, and M. Hickson. 2017. Dietary magnesium may be protective for aging of bone and skeletal muscle in middle and younger older men and women: Cross-sectional findings from the UK Biobank cohort. Nutrients 9:1189. https://doi.org/ $10.3390 /$ nu9111189.

WHO (World Health Organization). 1999. Technical Report Series 886. Programming for adolescent health and development. Accessed
Dec. 14, 2019. https://www.who.int/maternal_child_adolescent/ documents/trs_886/en/.

WHO (World Health Organization). 2019. World health statistics 2019: Monitoring health for the SDGs, sustainable development goals. WHO, Geneva, Switzerland.

WHO (World Health Organization). 2020. Vitamin and mineral nutrition information system (VMNIS), database on iodine deficiency. Accessed Apr. 26, 2020. https://www.who.int/vmnis/database/ iodine/en/.

WHO (World Health Organization) Secretariat, M. Andersson, B. de Benoist, F. Delange, and J. Zupan. 2007. Prevention and control of iodine deficiency in pregnant and lactating women and in children less than 2-years-old: Conclusions and recommendations of the technical consultation. Public Health Nutr. 10(12A):1606-1611. https://doi.org/10.1017/S1368980007361004.

Wilkins, E., L. Wilson, K. Wickramasinghe, P. Bhatnagar, J. Leal, R. Luengo-Fernandez, R. Burns, M. Rayner, and N. Townsend. 2017. European cardiovascular disease statistics 2017. Accessed Dec. 12, 2019. http://www.ehnheart.org/cvd-statistics/cvd-statistics-2017 .html.

Yakar, S., H. Werner, and C. J. Rosen. 2018. 40 Years of IGF1. Insulin-like growth factors: Actions on the skeleton. J. Mol. Endocrinol. 61:T115-T137. https://doi.org/10.1530/JME-17-0298.

Yang, Y., T. A. Churchward-Venne, N. A. Burd, L. Breen, M. A. Tarnopolsky, and S. M. Phillips. 2012. Myofibrillar protein synthesis following ingestion of soy protein isolate at rest and after resistance exercise in elderly men. Nutr. Metab. (Lond.) 9:57. https:// doi.org/10.1186/1743-7075-9-57.

Zempleni, J. 2017. Milk exosomes: Beyond dietary microRNAs. Genes Nutr. 12:12. https://doi.org/10.1186/s12263-017-0562-6.

Zia, A., H. U. Siddiqui, H. Mohiuddin, and S. Gul. 2018. Leveling-off of declining trend of cardiovascular disease-related mortality in the USA: The challenge to rein in obesity and diabetes epidemic. Cardiovasc. Endocrinol. Metab. 7:54-55. https://doi.org/10.1097/ XCE.0000000000000146.

\section{ORCIDS}

D. I. Givens @ https://orcid.org/0000-0002-6754-6935 